\title{
Variable verb placement in second-language German and French: Evidence from production and elicited imitation of finite and nonfinite negated sentences
}

\author{
SARAH SCHIMKE \\ Max Planck Institute for Psycholinguistics and Laboratoire Structures \\ Formelles du Langage, CNRS and Université Paris 8
}

Received: December 28, 2008 Accepted for publication: May 2, 2010

\begin{abstract}
ADDRESS FOR CORRESPONDENCE
Sarah Schimke, Department of German Studies, University of Osnabrück, Neuer Graben 40, Osnabrück 49074, Germany. E-mail: sarah.schimke@uni-osnabrueck.de
\end{abstract}

\begin{abstract}
This study examines the placement of finite and nonfinite lexical verbs and finite light verbs (LVs) in semispontaneous production and elicited imitation of adult beginning learners of German and French. Theories assuming nonnativelike syntactic representations at early stages of development predict variable placement of lexical verbs and consistent placement of LVs, whereas theories assuming nativelike syntax predict variability for nonfinite verbs and consistent placement of all finite verbs. The results show that beginning learners of German have consistent preferences only for LVs. More advanced learners of German and learners of French produce and imitate finite verbs in more variable positions than nonfinite verbs. This is argued to support a structure-building view of second-language development.
\end{abstract}

Characterizing the syntactic knowledge that adult learners have in the language they are acquiring is a central issue in second-language (L2) acquisition research. In particular, because nontargetlike morphosyntactic structures are frequently observed in the speech of beginning L2 learners (see, e.g., Klein \& Perdue, 1997), researchers have proposed that the underlying syntactic knowledge of learners is fundamentally or partially different from nativelike syntax (Beck, 1998; Eubank, 1993/1994, 1996; Meisel, 1997) or that it only reaches a nativelike state after a gradual structure-building process (Dimroth, Gretsch, Jordens, Perdue, \& Starren, 2003; Vainikka \& Young-Scholten, 1994, 1996a, 1996b). Other researchers, however, have proposed that target-deviant utterances are due to problems with the surface realization of morphology and that syntactic representations of L2 learners are nativelike even at stages at which superficial errors occur (Herschensohn, 
2001; Lardiere, 1998; Prévost \& White, 2000). Verb placement in negated contexts allows us to test these different proposals by determining whether learners have knowledge of the relation between finiteness marking on the verb and its placement with respect to the negator. Studies to date have investigated the relation between finiteness and negation in learners' spontaneous production (e.g., Meisel, 1997; Parodi, 2000; Prévost \& White, 2000). These studies have come to conflicting conclusions, however, in particular with respect to early stages of development, at which finite forms are infrequent in spontaneous production. The present study aims at complementing the existing evidence by providing data both from semispontaneous production and a more controlled elicited imitation task, conducted with 48 beginning Turkish learners of German and 43 beginning Turkish learners of French.

The remainder of the introductory section briefly describes the relevant properties of the target languages as well as the source language. Subsequently, previous studies on the relation between finiteness and verb placement in L2 are reviewed. It is shown that contradictory claims have been made, in particular concerning the placement of finite lexical verbs compared to nonfinite lexical verbs on the one hand and finite light verbs (LVs) on the other hand. Placement preferences for these three types of verb forms are then systematically compared in data from semispontaneous production and elicited imitation. The results from the present study provide evidence against permanent impairment of L2 grammatical representations. However, they also show that there is more variability in the placement of finite verbs than predicted by theories that assume nativelike syntax in early L2. The paper concludes with arguing that the results can best be explained on a structure-building account of L2 syntactic development. Furthermore, differences in the result patterns between the two investigated target languages are discussed and related to differences in word order between the two languages.

\section{FINITENESS AND NEGATION IN GERMAN, FRENCH, AND TURKISH}

Verb forms are considered finite if they are marked for agreement and tense, as opposed to unmarked nonfinite verb forms, such as infinitival and participle forms. In the analysis of the German and French L2 data of the present study, only (present tense) agreement marking was used to identify finite forms, as tense markings other than present tense were almost absent from the data, reflecting the low proficiency of the investigated learners. The agreement paradigms of spoken German and French are summarized in Table 1 for the regular verbs gehen/marcher ("to walk").

As for negation, the negator is assumed to be the head of a NegPhrase in German and French and to have a higher position in the phrase structure than the verb phrase (VP; Pollock, 1989). Finiteness is related to verb placement in negated contexts, because finite verbs raise over the negator to a higher verbal functional category whereas nonfinite verbs remain in the VP (Chomsky, 1995). As a result, finite verbs appear to the left and nonfinite verbs to the right of the negator in the surface form of the sentence. This is illustrated in (1a) and (2a) for German and (1b) and (2b) for French. Note that for French, the position of the verb is only discussed with respect to the postverbal negator pas in this paper, not taking into account 
Table 1. Present tense agreement paradigms and nonfinite forms in spoken German and French

\begin{tabular}{cll}
\hline \hline & \multicolumn{1}{c}{ German } & \multicolumn{1}{c}{ French } \\
\hline $1 \mathrm{sg}$ & ich geh-/ə// geh-0 & je march-0 \\
$2 \mathrm{sg}$ & du geh-/st/ & tu march-0 \\
$3 \mathrm{sg}$ & er geh-/t/ & il march-0 \\
$1 \mathrm{pl}$ & wir geh-/ən/ & nous march-/õ/ (formal) \\
& & on march-0 (informal) \\
$2 \mathrm{pl}$ & ihr geh-/t/ & vous march-/e/ \\
$3 \mathrm{pl}$ & sie geh-/ən/ & ils march-0 \\
Infinitive & geh-/ən/ & march-/e/ \\
Past participle & ge-gang-/ən/ & march-/e/ \\
\hline \hline
\end{tabular}

Note: Because all data discussed in this paper are oral as opposed to written, phonetic transcriptions of the suffixes are given to demonstrate ambiguities that exist in spoken language but not written language. In French, only the suffixes for the most frequent verb group are given, namely, for verbs ending in -er. Verbs of other groups have a different infinitival (-re, -oir, or -ir) and participial (- $u$ or $-i)$ ending, but in most cases the suffixes used for finite forms are the same as in Table 1. Note that in colloquial German the schwa forms can be omitted (Behrens, 1993).

$n e$, which occurs preverbally in standard French but is very frequently omitted in colloquial French. This follows previous studies on the same topic (Meisel, 1997; Prévost \& White, 2000; Rule \& Marsden, 2006).

(1a) Hans geht nicht

(1b) Jean (ne) marche pas

John walk ${ }_{\text {FIN }}{ }^{1}$ not

"John does not walk"

(2a) Hans möchte nicht gehen

(2b) Jean (ne) veut pas marcher

John want FIN not walk INF

"John does not want to walk"

Finite LVs, for example, modal verbs, auxiliaries, and the copula, do not differ from finite lexical verbs in appearing to the left of the negator in both languages, as illustrated in (2). For French, it has been assumed that LVs raise from a position lower than NegP in the same way as finite lexical verbs (Pollock, 1989). For German, it is controversial whether LVs raise (as assumed for instance by Parodi, 2000) or are base-generated in a position higher than NegP (as assumed, i.e., by Vainikka \& Young-Scholten, 1996a). In both cases, they behave identically to finite lexical verbs in the surface form of negated sentences.

The contingency between finiteness marking on the verb and its position with respect to the negator not only holds in adult native speakers, but it can also even be 
observed in early child language in both German and French. Children's first verb forms are generally nonfinite, and these verbs appear to the right of the negator in negated utterances. As soon as finite verb forms are used, they are placed in a raised position to the left of the negator (Poeppel \& Wexler, 1993, for German; Pierce, 1989, 1992, for French). The contingency between finiteness and verb raising has been taken as evidence that children have adultlike syntactic representations at this stage of development (Poeppel \& Wexler, 1993). Their grammar comprises a verbal functional category above NegP to which finite verbs move. ${ }^{2}$ This finding from early child language raises the question whether the same is true for adult learners at early stages of development: do L2 grammars also comprise a verbal functional category above NegP? This would predict that verb raising occurs in adult learner language as well. If this is the case, one might further ask whether the nature of the category is the same as in native speakers. If so, finite verbs should obligatory raise to this category, whereas nonfinite verbs should always remain in their position below the negator.

According to some, the relation between finiteness and verb placement with respect to negation in $\mathrm{L} 2$ might be influenced by whether a similar relation holds in the source language of the investigated learners. Turkish is a verb-final language, in which finite verbs normally appear to the right of all other clausal elements. There are three ways of expressing sentential negation, illustrated for instance in Haznedar (1997). In sentences that contain a verb, negation is expressed by the negative suffix $-m A$, as in (3):

(3) (Biz) dün toplantıya katıl-ma-dı-k

(We) yesterday meeting attend-neg-past-1pl

"We did not attend the meeting yesterday"

(Haznedar, 1997, p. 246)

It is assumed that each of the verb suffixes projects a functional head and that the verb moves string-vacuously through these heads to AgrP (Haznedar, 1997; Ouhalla, 1991). In verbless clauses, two other negative elements are used, değil ("not") and yok ("not exist"), which carry tense and agreement suffixes and appear clause-finally, similar to inflected verb forms: see (4) and (5).

(4) (Siz) bir yazar değil-di-niz.

(you) a writer not-past-2sg

"You were not a writer."

(Haznedar, 1997, p. 246)

(5) Dün sizi ara-dl -m ama evde yok-tu-nuz.

yesterday you call-past-1sg but house not.exist-past-2sg

"I called you yesterday but you were not at home."

(Haznedar, 1997, p. 246)

Turkish has no LVs expect for a modal verb istemek, "want," that appears clause-finally and on which negation, tense, and agreement suffixes appear in the same order as on other finite verbs. To sum up, Turkish differs from both French and German in that finite verbs do not raise over independent clausal elements, but appear clause-finally. The negation suffix follows the verb stem, but both this suffix and free negative morphemes precede finiteness markers. 


\section{FUNCTIONAL CATEGORIES IN L2}

Approaches to the existence and nature of functional categories in L2 grammars can be classified into two types of accounts. On the one hand, there are deficitbased accounts that assume differences between learners' and native speakers' functional category systems and consequently attribute target-deviant utterances to these differences. On the other hand, there are full competence-based accounts that assume a very rapid development of nativelike functional categories in L2 and attribute target-deviant utterances to nonsyntactic difficulties.

\section{Deficit-based accounts}

According to the fundamental difference hypothesis (Bley-Vroman, 1990; Clahsen, 1988, 1990; Clahsen \& Muysken, 1986; Meisel, 1991, 1997), it is impossible for adult learners of an L2 to acquire nativelike syntactic structures. It is argued that learners can succeed in forming superficially nativelike utterances by acquiring knowledge about "linear strings of elements encountered in utterances, not hierarchical syntactic sentence structures" (Meisel, 1997, p. 228). Thus, proponents of this view assume that L2 grammars are fundamentally different from native grammars, and that abstract syntactic structures, such as functional categories, are unavailable at all stages of development.

Other researchers propose that functional categories as such exist in L2 syntactic representations, but that the functional category system is not nativelike in every respect. In particular, it has been claimed that properties of the functional category system that do not exist in the first language (L1) cannot be acquired in an L2 (Franceschina, 2001; Hawkins, 2000; Hawkins \& Chan, 1997; see also the studies in Snape, Leung, \& Sharwood Smith, 2009). With respect to finiteness, it has been proposed that verbal feature representations are impaired in L2 grammars (Beck, 1998; Eubank, 1993/1994, 1996). According to this proposal, feature strength is underspecified in L2 grammars, and as a consequence, verb raising is optional at all stages of L2 development. Finally, researchers have suggested that functional categories are the result of a gradual structure-building process (Dimroth et al., 2003; Vainikka \& Young-Scholten, 1994, 1996a, 1996b). According to this approach, early learner grammar only comprises a VP, but no higher verbal functional projections. These would then be built up gradually, passing through a stage of optional verb raising (Vainikka \& Young-Scholten, 1996a, 1996b). Note that structure-building accounts are not deficit-based accounts in a narrow sense, because the building up of functional categories is assumed to take place in a similar fashion in L1 acquisition and no difference is assumed between native speakers and L2 learners at the end stage of development in this domain, when agreement marking has become stable.

To sum up, deficit-based accounts assume that functional categories are absent (Dimroth et al., 2003; Meisel, 1991, 997; Vainikka \& Young-Scholten, 1996a, 1996b) or impaired (Beck, 1998; Eubank, 1996) in early L2 grammars. This state of the grammar is either assumed to be permanent (Eubank, 1996; Meisel, 1997) or transitory (e.g., Dimroth et al., 2003; Vainikka \& Young-Scholten, 1996a, 1996b). Despite the differences between the theories, they make the common assumption 
that L2 syntactic representations are nonnativelike at early stages and that this causes nontargetlike surface forms. This common hypothesis will be referred to as syntactic deficit hypothesis (SDH). Under the SDH, agreement marking as well as verb raising are expected to be unstable and unrelated phenomena in early L2.

\section{Full competence-based accounts}

In contrast to deficit-based accounts, other researchers have claimed that L2 learners start out with a full functional category system from the onset of acquisition on. The initial syntactic representations are assumed either to be provided by universal grammar (Epstein, Flynn, \& Martohadjiono, 1996), or to consist of the representations of the L1 that are transferred to the L2 grammar (Schwartz \& Sprouse, 1994, 1996). According to the second view, known as full transfer/full access hypothesis (Schwartz \& Sprouse, 1996), the learners investigated in the present study should thus attempt to assign the grammar underlying Turkish negation to German and French negated clauses. As shown above, finite verbs appear clause-finally in Turkish. Schwartz and Sprouse (1996) conclude from this that Turkish learners should not be able to assign a representation to clauses containing raised verbs appearing to the left of negation or other clausal elements: "Every single German utterance consisting of a main clause made up of more than just the subject and a single finite verb (i.e., $\mathrm{SV}_{[+\mathrm{F}]}$ ) will be incompatible with the grammatical system transferred from Turkish" (Schwartz \& Sprouse, 1996, p. 44). The authors state that this "necessarily" leads to a rapid restructuration of the system: "As soon as ... [the learner] develops enough vocabulary recognition to understand the meaning of short sentences, the inability of his system to assign a representation to such sentences will necessarily lead to (UG-constrained) restructurings of the system" (Schwartz \& Sprouse, 1996, pp. 44 and 45).

In sum, both types of full competence approaches predict that L2 learners very rapidly adapt their functional category system to a target language-compatible setting, and that they are thereby guided by the same universal grammar based knowledge that is assumed to be at work in L1 acquisition. Consequently, the contingency between finiteness and verb placement observed in L1 is expected to be present in L2 data: finite verbs should precede, and nonfinite verbs follow the negative element.

There is a frequent exception to this contingency, however: several researchers have pointed out that unlike in L1 acquisition, nonfinite verbs in raised positions frequently occur in L2 data (Herschensohn, 2001; Ionin \& Wexler, 2002; Lardiere, 1998; Prévost \& White, 2000; Schlyter, 2003). To account for this phenomenon, it has been claimed by the above-cited authors that the unexpected use of nonfinite forms is due to morphological rather than syntactic problems. According to this hypothesis (termed the missing surface inflection hypothesis [MSIH]; Prévost \& White, 2000), the process of selecting the correct morphological form to insert into a given syntactic position can sometimes fail in an L2. If selection of the intended form fails, default forms are used. Crucially, nonfinite forms are assumed to be such default forms. The MSIH therefore predicts that nonfinite forms can appear to the left of the negator when used as default forms and to its right when they are genuinely nonfinite. Finite forms should occur to the left of the negator exclusively, 
and this should be the case from their first uses onward. The empirical evidence on the placement of finite and nonfinite forms in negated contexts in L2 is reviewed in the following section.

\section{EVIDENCE FROM FINITENESS AND NEGATION IN L2 ACQUISITION}

Empirical studies on finiteness and negation in L2 have come to conflicting conclusions. With respect to finite verbs, many have made a distinction between finite LVs and finite lexical verbs (for an overview, see Parodi, 2000). For finite LVs, there is converging evidence on the empirical facts, but no agreement on the interpretation of the findings. For finite lexical verbs, observations as well as interpretations are contradictory across studies. Finally, researchers have made converging observations on the placement of nonfinite lexical verbs, but again differed in their conclusions. In the following, empirical results concerning each of these three kinds of verb forms are presented in more detail. First, the findings on finite LVs and nonfinite lexical verbs are presented. Second, the more contradictory findings for finite lexical verbs are summarized.

\section{The placement of finite LVs and nonfinite lexical verbs}

Researchers agree that LVs such as the copula, auxiliaries, and modal verbs almost always appear in a finite form and precede the negator in L2 German and French as well as in other target languages, at all stages of development (Giuliano, 2003; Parodi, 2000; Schwartz \& Sprouse, 1996; Vainikka \& Young-Scholten, 1996a). Whereas this finding is well established, it is controversial whether it allows for any conclusions about the existence of functional categories in L2 grammars. On the one hand, it has been argued that the presence of LVs in raised positions is evidence that the $\mathrm{L} 2$ grammar comprises a functional category providing this position. According to this account, what is delayed in L2 acquisition is finiteness marking on lexical verbs, not the functional category system and the relation between finiteness and verb raising as such (Ionin \& Wexler, 2000; Parodi, 2000; Zobl \& Liceras, 1994). On the other hand, that the negator follows LVs has also been taken as evidence for the idea that at least in early L2, language use is guided by semantic rather than syntactic principles. More precisely, it has been claimed that in early L2, the negator precedes the part of the utterance over which it has semantic scope. Lexical verbs typically fall into the scope of negation, whereas LVs, having no or little lexical content, usually fall out of its scope. This predicts that negation should follow LVs but precede lexical verbs and thereby gives an account for the placement of LVs in a "finite" position that is independent of finiteness (Becker, 2005; Bernini, 2000; Clahsen, Meisel, \& Pienemann, 1983; Jordens \& Dimroth, 2006; Meisel, 1983; Wode, 1981). The placement of finite LVs preceding the negator is thus compatible with the MSIH when a syntactic account is taken, but also with the SDH on a semantic account.

As for nonfinite lexical verbs, it is noteworthy that they appear frequently as main verbs in beginning L2 German and French, similar to what has been observed in L1 acquisition (Dimroth et al., 2003; Haznedar \& Schwartz, 1997; Klein \& Perdue, 1997). ${ }^{3}$ They predominantly appear after the negator in negated 
sentences but occasionally also precede the negator (Meisel, 1997; Parodi, 2000). This can also be explained by both approaches: proponents of the SDH take the variable placement as evidence for the absence of a systematic relation between finiteness and verb raising. Proponents of the MSIH claim that nonfinite forms in unraised positions are genuinely nonfinite, whereas nonfinite forms in raised position are default forms that are underlying finite (Herschensohn, 2001; Prévost \& White, 2000; Rule \& Marsden, 2006).

\section{The placement of finite lexical verbs}

With respect to the placement of finite lexical verbs, conflicting results have been reported. In studies on L2 French, researchers have claimed that finite lexical verbs behave as finite LVs in exclusively preceding the negator (Herschensohn, 2001; Rule \& Marsden, 2006). However, the learners in these studies received explicit instruction and had no contact with the target language outside this setting. Maybe as a consequence they used predominantly postverbal negation, and both nonfinite and finite forms were thus rarely found behind the negator. In studies on uninstructed naturalistic learners of both L2 German and L2 French, several researchers have reported the occasional appearance of finite verbs following the negator besides their placement preceding it (Becker, 2005; Giuliano, 2003; Meisel, 1997; Parodi, 2000; Prévost \& White, 2000; Vainikka \& Young-Scholten, 1996a, 1996b). However, only Meisel (1997) concludes from this that syntactic representations are impaired. The other researchers doubt whether the finite forms observed in nonfinite positions are "truly finite" for the learner. For German, the (potentially) finite forms most often observed in unraised positions are the bare stem or forms ending in $-e$. These forms have been claimed to be default forms in learner language (Parodi, 2000; Prévost \& White, 2000; Vainikka \& YoungScholten, 1996b). In French, most of the finite verb forms are homophonous with the bare stem, which has also been claimed to be analyzed as a default form by learners of French (Prévost, 2004). In addition to that, Prévost and White (2000) show that the incidence of finite forms in nonfinite positions is lower than the incidence of nonfinite forms in finite position in the data of two learners of French and two learners of German they investigate. They argue that if it is true that learners have no access to nativelike syntactic representations, as claimed by the $\mathrm{SDH}$, then there is no reason why deviations from the target pattern should occur more often in one direction than in the other. The authors do not discuss, however, that finite forms are in general much more frequent than nonfinite forms in their data, which are longitudinal data collapsed over time points. More precisely, $79 \%$ of all verb forms investigated by Prévost and White in negated contexts in L2 French were finite forms, as well as $72 \%$ of all forms investigated in negated contexts in L2 German. It thus seems that these data as a whole are representative for a developmental stage at which finite forms represent the majority of the verb forms used. It remains unclear whether the high percentage of correct placement of finite forms in these data is already in place at earlier stages, and whether target-deviant placements of nonfinite forms outnumber target-deviant placements of finite forms from the start, as claimed by the authors. Moreover, it seems worthwhile to test whether the observed tendencies hold for more than 
the four learners investigated in this study, and generalizes to L2 learners in general.

To sum up, the available evidence has been taken to support the SDH or the MSIH by different researchers. The data in Prévost and White (2000) suggest that, in line with the MSIH, there is less variability in the placement of finite than of nonfinite verbs. It remains unclear, however, whether this pattern is in place from the earliest occurrences of finite verb forms onward. The investigation of this question is hindered by there being few occurrences of unambiguously finite lexical verbs at early stages of development, at which learners mainly rely on predominantly nonfinite default forms. Conclusions regarding early states of L2 grammars therefore hinge on the interpretation that researchers make of isolated occurrences of finite forms. In order to test the predictions of the SDH and the MSIH at stages at which spontaneously produced unambiguously finite forms are relatively infrequent, it is desirable to compare the behavior of finite lexical verbs to finite LVs and nonfinite lexical verbs by using controlled tasks, in which an equal number of data points can be elicited for each of these verb types in comparable contexts. If the SDH is correct, a consistent placement of verbs should not depend on finiteness but might depend on semantic lightness: there should be variability for finite (and nonfinite) lexical verbs and, if there are consistent preferences, they should be restricted to LVs. If the MSIH is correct, not lightness, finiteness should matter: from the start, learners should have consistent preferences for finite lexical verbs as well as for finite LVs and show variability only for nonfinite lexical verbs.

\section{THE PRESENT STUDY}

The aim of the present study is to test the competing theories of L2 syntactic knowledge by comparing the placement of finite lexical verbs to the placement of finite LVs and nonfinite lexical verbs in learner language. Data stem from a relatively large group of beginning Turkish learners of German and French. Two different tasks were used: a semispontaneous production task, in which short retellings of picture stories and a movie were elicited, and an elicited imitation task, in which similar structures were investigated as in the semispontaneous production data. Results of both tasks are taken together in order to determine whether lightness or finiteness is the crucial factor for a consistently raised position of the verb at early developmental stages.

Note that although clear criteria can be established for the distinction between lexical and LVs, identifying unambiguously nonfinite and finite lexical verb forms is difficult in the two target languages. In French, it is unavoidable that finite forms are typically homophonous to the bare stem, which will be taken into account in the discussion of the results. In German, the first and third person plural forms (ending in -en) are homophonous to the infinitive. For this reason, the present investigation focuses on third person singular contexts. In this context, nonfinite forms are clearly distinguishable from the expected finite form, ending in $-t$. The restriction to third person singular contexts thus ensures that the classification of verb forms as finite or nonfinite is unproblematic. As noted by an anonymous reviewer, that the surface form classification is straightforward does not mean that the forms in question are unambiguously finite or nonfinite also in the mind of 
the learner. However, it is true that the predictions of the SDH and the MSIH (necessarily) concern the distribution of surface forms. Whereas the SDH expects variable occurrences of finite forms in different syntactic contexts, the MSIH claims that finite surface forms are finite also in the mind of the learner, and should therefore not be placed randomly: “. . . on the MSIH, finite forms are assumed to be genuinely finite... Thus, we predict that finite verbs will be found only in finite contexts" (Prévost \& White, 2000, p. 111). Although Prévost and White (2000) then attenuate this prediction for forms ending in $-e$, noting that these might be considered default forms in German, forms ending in $-t$ clearly belong to the forms to which their prediction pertains. Observing the occurrence of $-t$ forms in finite and nonfinite contexts is thus a valid way of testing this prediction. The status of these forms in the learner system will be further discussed after the presentation of the results.

\section{PARTICIPANTS}

Participants were adult native speakers of Turkish, 48 of them ( 30 female, 18 male) acquiring German and 43 of them ( 28 female, 15 male) acquiring French. The average age was 32.5 years in the learners of German and 34 years in the learners of French. All participants were acquiring the target language in an immersion setting, having immigrated to Germany or France, respectively. The learners of German had been living in Germany for 9 years on average, the learners of French had been living in France for 8 years on average at the moment of testing. Many of the learners (52\% of the learners of German and 56\% of the learners of French) had only limited contact to the target language. This means that they did not work in a French- or German-speaking environment and had no close friends or family who used the target language regularly. The remaining participants had more contact with the target language, but continued to use Turkish on a daily basis. Learners had received limited language teaching prior to the time of testing (6 months on average for the learners of German and 9 months on average for the learners of French). The educational background of the learners was low in general ( 9 years of schooling on average in the learners of German and 8 years in the learners of French). Participants' use of morphosyntax clearly corresponds to a beginning stage of acquisition, as evidenced in particular by the presence of an important number of nonfinite utterances in the production data, as well as the near absence of other than present tense finite morphology and complex syntactic structures such as subordinate clauses (see also Klein \& Perdue, 1997; Vainikka \& Young-Scholten, 1994; Verhagen, 2009, who similarly observe that long-term residents can be at a low stage of proficiency). The current learner sample thus clearly represents a stage of proficiency that is of interest to theories of beginning L2 syntax. It represents this proficiency level as it can be observed in a particular type of population, namely, a population of slow and probably partially fossilized learners. There are indications that the acquisition of finiteness and verb placement proceeds in a remarkably similar fashion in different types of (untutored) learners (Dimroth et al., 2003; Verhagen \& Schimke, 2009). Nevertheless, it should be noted that generalizations from the present data beyond the specific type of learners 
investigated here are problematic. Detailed information about the learners can be found in Appendix A.

\section{SEMISPONTANEOUS PRODUCTION}

The semispontaneous production data consisted of oral retellings of three picture stories developed by Verhagen $(2005,2009)$ and a short silent movie developed by Dimroth (The Finite Story, Dimroth, 2006). The elicitation tools prompted the use of utterances in third person singular contexts and provided several contexts for eliciting negated utterances. After exclusion of unclear cases (see below), these materials elicited on average 50 verb-containing utterances in third person singular contexts per learner, of which an average of 3.2 per learner were negated utterances.

\section{Procedure}

Both the picture stories and the silent movie were shown on a laptop computer to each participant individually. The picture stories consisted of between 9 and 11 pictures. Participants were first shown each story once, and then saw it again picture by picture, retelling the content of every picture immediately after having seen it. The movie consisted of a series of extremely simple actions (such as "sleeping," "getting up," and "seeing a fire") and was presented in short separate scenes, each consisting of not more than two of these actions. Participants retold the content of each scene immediately after having seen it, and before proceeding to the next scene. The investigator watched the stories and the movie together with the participants, and it was clear that she was familiar with the materials. This has probably led to different retellings than if there had been no mutual knowledge, in particular, concerning the use of referring expressions. It seems unlikely, however, that mutual knowledge had an influence on the use of finiteness in negated utterances by the participants. All retellings were transcribed and coded for the form and placement of verbs.

\section{Coding}

All verb-containing utterances in third person singular contexts were selected. Self-repetitions and imitations of the researchers' utterances were excluded, as well as subordinate clauses and unclear syntactic structures due to restarts and reformulations. Moreover, utterances in French were excluded if it could not be decided whether the main verb was a lexical verb only or whether a combination of a LV and a lexical verb was present. This happened frequently when learners produced elements preceding lexical verbs that resembled clitic object pronouns, as these elements can be ambiguous between a pronoun and a combination of a pronoun and a LV, especially in the pronunciation of some learners. As a consequence, an utterance such as Monsieur le dort was considered to be ambiguous between Monsieur le dort ("Mister him sleeps") and Monsieur l'est dort ("Mister him is sleeps"). Note that the data strongly suggest that these elements are taken over as unanalyzed and seemingly meaningless chunks by the learners. There is 
Table 2. Order of verb and negator for different verb forms in German and French

\begin{tabular}{lrrrrr}
\hline \hline & \multicolumn{2}{c}{ German } & & \multicolumn{2}{c}{ French } \\
\cline { 2 - 3 } \cline { 6 - 7 } & V-Neg & Neg-V & & V-Neg & Neg-V \\
\hline Light verbs +fin & 49 & 0 & & 75 & 1 \\
Lexical verbs -fin & 3 & 58 & & 6 & 11 \\
Lexical verbs +fin & 15 & 7 & & 32 & 7 \\
\hline \hline
\end{tabular}

no evidence that they function as object pronouns in their speech (see also Myles, 2004). Utterances containing the sequence ne pas as in il ne pas entendu were likewise excluded because they were considered to be ambiguous between il ne pas entendu ("he not heard") and il n'est pas entendu ("he is not heard"). As the use of the negative particle $n e$ was very scarce in the data, only seven negated utterances had to be excluded for this reason.

Modal verbs, auxiliaries, possessive "have" and the copulae "to be" (sein/être) and "to become" (werden) were coded as LVs (following Parodi, 2000). ${ }^{4}$ LVs and lexical verbs were coded as finite when they appeared in the correct form for third person singular, as nonfinite when they appeared in the infinitive or past participle form, and as other forms when learners used a finite form that was however not the correct third person singular form. Other forms were excluded from further analysis, as it is unclear whether they should be considered finite (because they are not infinitival forms), or nonfinite (because they are not correctly marked for agreement). In cases in which, in French, a finite form was homophonous with the nonfinite past participle, the form in question was treated as the form that would be grammatical in the given context. Note that this ambiguity never occurred in negated contexts. For German lexical verbs, the presence of the - $t$ suffix was considered a sufficient agreement marker, changes of the stem were not taken into account, as these can be considered to reflect not only grammatical, but also lexical knowledge. Third person singular forms of "to be" that were reduced from ist to is were coded as finite and correctly agreeing, as the resulting form is not homophonous with the bare stem, sein. Furthermore, overgeneralizations of the $-t$ morpheme to modal verbs (leading for instance to willt instead of will) were also counted as finite and correctly agreeing verb form. Finally, German verbs appearing as bare stems were counted as other forms and therefore excluded from analysis.

\section{Results}

Table 2 shows the placement of the different kinds of verb forms with respect to the negator for all learners of German and French, respectively. ${ }^{5}$

The results show that all three kinds of verb forms behave differently from each other. Finite LVs almost exclusively precede the negator, whereas there are some exceptions from this placement for finite lexical verbs. This leads to a significant contingency between verb type (finite lexical verb vs. finite LV) and placement in both target languages (Fisher's exact test in German, $p<.001$; Fisher's exact test in French, $p<.005){ }^{6}$ However, finite lexical verbs also differ from nonfinite lexical 
verbs that predominantly follow the negator, leading to a significant contingency between finiteness marking and placement for lexical verbs in both languages: Fisher's exact test in German, $p<.001$; Fisher's exact test in French, $\chi^{2}(1)=$ $11.9, p=.001$. Examples for negated utterances with different verb forms are given in (6) through (14). They all stem from the descriptions of a scene in which one protagonist of the film, Mr. Green, does not jump out of the window, although there is a fire in his house.

$L V$, raised position:

(6) aber er hat nicht gespringt

but he has not jump pP

"aber er ist nicht gesprungen"

but he is not jump $_{P P}{ }^{7}$

(7) il veut pas saut/e/

he want not jump INF.PP

nonfinite lexical verb, raised position:

(8) tomb/e/ pas

fall INF.PP not

"(monsieur vert) tombe pas"

(mr. green) fall $\mathrm{FIN}$ not

nonfinite lexical verb, unraised position:

(9) herr grün nicht fallen

mr. green not fall INF

"herr grün fällt nicht"

mr. green fall FIN not.

(10) pas tomb/e/

not fall INF.PP

"(monsieur vert) tombe pas"

(mr. green) fall FIN not

finite lexical verb, raised position:

(11) aber herr grün springt nicht but mr. green jump FIN not

(12) il saute pas he jump FIN not

finite lexical verb, unraised position:

(13) nicht springt $^{8}$

not jump FIN

"(herr grün) springt nicht"

(mr. green) jump FIN not

(14) il pas saute

he not jump FIN

"il saute pas"

he jump FIN not

The significant relation between finiteness marking and verb placement for lexical verbs is unexpected according to the SDH. In contrast, the occasional placement of finite lexical verbs in unraised positions is unexpected according to the MSIH. 
Table 3. Order of verb and negator for different verb forms in low-agr groups

\begin{tabular}{lccrrr}
\hline \hline & \multicolumn{2}{c}{ German } & & \multicolumn{2}{c}{ French } \\
\cline { 2 - 3 } \cline { 5 - 6 } & V-Neg & Neg-V & & V-Neg & Neg-V \\
\hline Light verbs +fin & 4 & 0 & & 31 & 0 \\
Lexical verbs - fin & 2 & 36 & & 6 & 5 \\
Lexical verbs +fin & 5 & 2 & & 20 & 4 \\
\hline \hline
\end{tabular}

The presented analysis collapses, however, different proficiency levels, and this might be problematic. More precisely, as discussed above, the apparent contingency between finiteness and verb placement could be due to more advanced learners in the sample only. At the same time, the most problematic exceptions to the contingency, the occurrences of finite forms in nonfinite positions, could be due to less advanced learners only. If finite forms are misplaced only by beginning learners, this could mean that the SDH is correct only for beginning phases, whereas the MSIH is a correct characterization of the grammar of more advanced learners.

To investigate whether the systematicity of agreement marking is related to the relation between finiteness and verb placement, a median split was made in both learner groups according to the percentage of correct agreement marking on all lexical verbs in third person singular contexts. The percentage of correct agreement in this context is displayed in Appendix B for every learner. In the learners of German, there were 24 learners who produced between $0 \%$ and $32 \%$ correct agreement $($ mean $=13.88 \%)$ and 24 who produced between $32.4 \%$ and $94 \%$ correct agreement $($ mean $=55.58 \%)$. In the learners of French, there were 22 learners who produced between $0.02 \%$ and $60 \%$ correct agreement $($ mean $=37 \%)$ and 21 learners who produced between $62 \%$ and $100 \%$ correct agreement (mean $=$ $77 \%$ ). Obviously, the median of the percentage of correct agreement is an arbitrary division point. It is not assumed here that this corresponds to a classification of learners into developmental stages. Moreover, it cannot be assumed that the split leads to comparable groups across target languages. Despite these limitations, the median split can be useful for investigating whether the rate of correct agreement matters in the investigated domain. More precisely, if the two groups resulting from the split behave differently, one can conclude that the rate of agreement matters and subsequently constrain conclusions to learners in a specific range of correct agreement. If they do not differ, it might still be the case that there are subgroups in the population that have not been detected by the split. ${ }^{9}$ The results for the groups in which agreement was marked less frequently (low-agr groups in the following) are displayed in Table 3.

The preferred pattern is not the same in the low-agr groups in the two target languages: whereas in French there is a preference for finite verbs in raised positions, in German the dominant type of negated utterances are nonfinite verbs in unraised positions. However, although the number of cases for finite verbs in German and nonfinite verbs in French is low, the relation between finiteness and verb placement 
Table 4. Order of verb and negator for different verb forms in high-agr groups

\begin{tabular}{lrrrrr}
\hline \hline & \multicolumn{2}{c}{ German } & & \multicolumn{2}{c}{ French } \\
\cline { 2 - 3 } \cline { 5 - 6 } & V-Neg & Neg-V & & V-Neg & Neg-V \\
\hline Light verbs +fin & 45 & 0 & & 44 & 1 \\
Lexical verbs - fin & 1 & 22 & & 0 & 6 \\
Lexical verbs +fin & 10 & 5 & & 12 & 3 \\
\hline \hline
\end{tabular}

is significant in German (Fisher's exact test, $p<.001$ ) and marginally significant in French (Fisher's exact test, $p=.07$ ). Verb placement is thus not random even before agreement marking has become systematic. In particular, it does not seem to be the case that all deviations from expected placements appear in the lowagr groups. This becomes more evident when looking at the data of the groups in which agreement was marked in more than $32 \%$ of all considered cases in German and more in than $62 \%$ in French (high-agr groups in the following), which are displayed in Table 4.

As expected, there is a contingency between finiteness and verb placement for lexical verbs in these groups (Fisher's exact test for German, $p<.001$; Fisher's exact test for French, $p<.005)$. However, the placement of finite lexical verbs continues to be less systematic than the placement of LVs, leading to a significant contingency between verb type and placement for finite verbs (Fisher's exact test for German, $p<.001$; Fisher's exact test for French, $p=.045$ ). In particular, there is no evidence that the error pattern is asymmetric in the way proposed by Prévost and White (2000): there are more exceptions in the placement of finite than of nonfinite verbs.

Summing up, all three kinds of verbs behave differently at both proficiency levels in both target languages. Finite LVs consistently appear in a raised position, whereas there are some exceptions from this placement for finite lexical verbs. Nonfinite lexical verbs are predominantly placed in an unraised position.

\section{Discussion}

The data are problematic for both approaches to L2 syntactic knowledge: the SDH cannot explain the contingency between verb form and verb position for lexical verbs that seems to exist even in the lowest proficiency groups. For the $\mathrm{MSIH}$, it is unexpected that finite lexical verbs differ from LVs, but do not differ from nonfinite lexical verbs in the number of deviant placements, respectively, and that this pattern persists in the more advanced learners. However, similar to previous studies investigating spontaneous or semispontaneous production, there are several limitations to the data.

First, there is a risk of overestimating the contingency between finiteness and verb placement in this type of data. This is the case because it cannot be excluded that some of the investigated utterances are composed of chunks of verbs and negators taken over from the input in an unanalyzed way. It has been shown that 
such unanalyzed chunks are often used in early L2 (Myles, 2004; Myles, Mitchell, $\&$ Hopper, 1999). Instances of unanalyzed chunks are particularly likely to distort the pattern when the overall number of cases is low, as is the case for finite verb forms in the low-agr group in German. As it might be that some instances of finite verbs followed by a negator were unanalyzed chunks, it seems premature to take these utterances as evidence for nativelike syntactic representations.

Second, it is similarly difficult to draw strong conclusions from the occasional placement of finite lexical verbs in unraised positions in the high-agr groups. They might point to an optionality of verb raising, but as their number is small overall, they also might constitute random performance errors. To avoid the problem of having to arbitrate between the SDH and the MSIH on the basis of a small number of cases, an elicited imitation task was used to complement the semispontaneous production data.

\section{ELICITED IMITATION}

The use of the elicited imitation task relies on the well-established finding that the meaning of linguistic material is remembered much longer than its precise form (see among others, Anderson, 1974; Bartlett, 1932; Begg, 1971; Binet \& Henry, 1894; Bock \& Brewer, 1974; Fillenbaum, 1966; Johnson-Laird \& Stevenson, 1970; Sachs, 1976; Wanner, 1974). For example, Sachs (1976) showed in a recognition task that shortly after having heard a sentence, native speakers were no longer able to discriminate that sentence from an alternative sentence that was only formally different (active vs. passive voice), although they could still distinguish it from a sentence expressing an alternative meaning. Similarly, Bock and Brewer (1974) showed in a recall task that participants made more changes affecting the form than affecting the meaning of stimulus sentences when trying to recall them. Moreover, the formal changes participants made were such that they changed sentences to a form that they had judged superior in an independent judgment task, relative to the form in which the sentence was originally presented. More precisely, Bock and Brewer report a "large asymmetry in the recall data, with the preferred forms recalled correctly more frequently than the nonpreferred forms and the nonpreferred forms showing more frequent shifts to the preferred forms than vice versa." (Bock \& Brewer, 1974, p. 843). These findings have been explained in terms of a reconstructive memory process. If it is impossible to retain a given stimulus sentence in working memory as a whole, subjects would presumably only retain the semantic gist of this sentence in long-term memory, and reconstruct its form when having to recall it (Binet \& Henry 1894; Bock \& Brewer, 1974). As a consequence, differences between the original stimuli and the repetitions reflect participants' syntactic and lexical preferences.

In language acquisition studies, these observations have been the basis for using elicited imitation as a measure of grammatical knowledge (for L1 acquisition: Kuczaj \& Maratsos, 1975; Lahey, Launer, \& Schiff-Myers, 1983; Slobin \& Welsh, 1968; Smith, 1973; for L2 acquisition: Epstein et al., 1996; Flynn, 1986; Hamayan, Saegert, \& Larudee, 1977; Markman, Spilka, \& Tucker, 1975; Munnich, Flynn, \& Martohardjono, 1994; Naiman, 1974; Verhagen, 2005, 2009; for a review, see Vinther, 2002). More precisely, it is assumed that when learners make changes to 
a sentence while repeating it, these changes should reflect, as they do for native speakers, linguistic preferences of the learners. These preferences can then reveal grammatical knowledge. In particular, grammatical knowledge can be tapped if learners are presented with stimuli that are ungrammatical in the target language: if they normalize ungrammatical sentences to their grammatical counterparts, while repeating grammatical versions of the sentence unchanged, it can be assumed that they have knowledge of the grammatical structure in question.

These types of normalizations were indeed found in studies that presented ungrammatical target sentences to (L1 or L2) learners: Kuczaj and Maratsos (1975) found that a 2-year-old English-speaking child consistently normalized utterances with misplaced auxiliaries. Similarly, Smith (1973) found that children between 3 and 4 years normalized various types of syntactically deviant sentences, while making much less changes when repeating the grammatical counterparts of these sentences. These results were replicated by Hamayan et al. (1977), using the same types of structures, with Arabic L2 learners of English. Finally, Verhagen (2005, 2009) found that Moroccan and Turkish L2 learners of Dutch normalized the placement of auxiliaries with respect to negation in ungrammatical sentences, while not altering sentences in which the auxiliary was placed in a targetlike position. It is important that Verhagen (2005, 2009) and Kuczaj and Maratsos (1975) report that normalizations of misplaced auxiliaries occurred in subject(s) who did not (yet) produce any auxiliaries in their spontaneous speech, suggesting that elicited imitation can reveal knowledge that is not (yet) visible in spontaneous production. Smith (1973) investigated the relation between spontaneous production and imitation in detail and found that there were three different types of structures in her data: structures that were spontaneously produced and normalized when presented in a deviant form during imitation, structures that were not spontaneously produced, but normalized, and structures that were neither spontaneously produced nor normalized in imitation. Instead, participants often rendered incomplete repetitions of the last type of structure or could not repeat it at all. Smith (1973) points out that the second type of structure is particularly interesting. She suggests that "perhaps with these structures we have cases of sentences that the children understand but do not use-sentences that are within their competence, but not to be found in their natural speech" (Smith, 1973, p. 512). Summing up, elicited imitation data seem to be suitable to confirm, in a controlled way, the presence of linguistic knowledge that can also be detected in spontaneous production, and, in addition, might reveal knowledge that is not yet visible in spontaneous production.

These previous findings suggest that elicited imitation yields data that can complement the semispontaneous production data presented so far in a useful way. Imitation data are close to (semispontaneous or spontaneous) production data as learners presumably rely on the same (unconscious) knowledge when reconstructing the sentence form in imitation that they also rely on in production. This makes production and imitation data more comparable to each other than, for instance, to data from conscious metajudgments of grammaticality. In addition, elicited imitation has the advantage over production of yielding a comparable amount of data on all relevant structures. Whereas learners might avoid the use of certain structures in production, they cannot avoid structures in the imitation task. 
Moreover, it is unlikely that participants can rely to a significant degree on the use of unanalyzed chunks in this task. They actively have to reconstruct meanings that they cannot choose themselves and for which they might not have such chunks at their disposal. Finally, elicited imitation can reveal knowledge about structures that learners do not (yet) use frequently in their spontaneous production, as is the case for finite lexical verb forms in parts of the present learner sample. It seems thus that this task is suitable for circumventing the problem of testing theoretical claims on the basis of a small number of instances.

Note that the validity of the task hinges on the participants not being able to hold the presented sentences in working memory. In native-speaker studies, this was achieved by introducing a delay between the presentation of the sentence and its repetition (e.g., Anderson, 1974; Sachs, 1976), or by introducing a secondary task that participants had to perform between the presentation of a sentence and its repetition (e.g., Bock \& Brewer, 1974). The studies conducted with language learners did not use such additional delays or tasks. The results suggest that a single sentence might already be too long to hold in working memory for this population, and lead to a reconstructive process during repetition. The current study followed previous elicited imitation studies with L2 learners, in having participants repeat sentences immediately after their presentation. Note that the length of the sentences was also comparable to those used in previous studies (in particular, Hamayan et al., 1977; Naimann, 1974; Verhagen, 2005, 2009). The stimuli included sentences with finite LVs, finite lexical verbs, or nonfinite lexical verbs in raised or unraised positions with respect to negation. Syntactic and morphological changes that occurred during the repetition of the sentence were analyzed in order to find out whether the patterns observed in learners' semispontaneous production could be confirmed in this more controlled task. More precisely, the behavior of finite lexical verbs was again compared to the behavior of finite LVs and nonfinite lexical verbs, in order to gain more conclusive evidence about the knowledge learners have about where these verb types should be placed with respect to the negator.

\section{Materials}

All items in the experiment were simple third person singular present tense declarative sentences composed of frequent lexical items (for a list of all experimental materials, see Appendix C).

Different items were used for LVs and lexical verbs. For LVs, eight sentences containing the auxiliaries haben in German and avoir in French were created. Only auxiliaries were used, as auxiliaries can be considered to constitute particularly clear cases of semantically light verbs, as opposed to, for instance, modal verbs (Parodi, 2000). In German, each sentence had between 10 and 13 syllables (average $=12.5$ ) and 9 words. In French, each sentence had between 10 and 13 syllables (average $=11.75$ ) and between 8 and 10 words (average $=9$ ). Each sentence could occur in one of two possible conditions: in a grammatical condition, in which the auxiliary appeared before the negator, and in an ungrammatical condition, in which the auxiliary was placed after the negator. Examples for both conditions are given in Table 5. 
Table 5. Light verb materials

\begin{tabular}{ll}
\hline \hline German: LV NEG & $\begin{array}{l}\text { Das Kind hat nicht mit dem tollen Spiel begonnen. } \\
\text { The child has not with the great game start-PP. }\end{array}$ \\
German: NEG LV & *Das Kind nicht hat mit dem tollen Spiel begonnen. \\
French: LV NEG & $\begin{array}{l}\text { L'homme a pas joué avec le jeune chien. } \\
\text { The man has not play-PP with the young dog. }\end{array}$ \\
French: NEG LV & *L'homme pas a joué avec le jeune chien. \\
\hline \hline
\end{tabular}

Table 6. Lexical verb materials

\begin{tabular}{|c|c|}
\hline German: -FIN NEG & $\begin{array}{l}\text { *Der Junge schreiben nicht an die traurige Tante. } \\
\text { The boy write -INF not to the sad aunt. }\end{array}$ \\
\hline German: NEG -FIN & *Der Junge nicht schreiben an die traurige Tante. \\
\hline German: +FIN NEG & Der Junge schreibt nicht an seine traurige Tante. \\
\hline German: NEG +FIN & *Der Junge nicht schreibt an seine traurige Tante. \\
\hline French: -FIN NEG & $\begin{array}{l}\text { *Le président habiter pas dans une grande maison. } \\
\text { The president live-INF not in a big house. }\end{array}$ \\
\hline French: NEG -FIN & *Le président pas habiter dans une grande maison. \\
\hline French: +FIN NEG & Le président habite pas dans une petite maison. \\
\hline French: NEG +FIN & *Le président pas habite dans une petite maison. \\
\hline
\end{tabular}

For lexical verbs, 16 sentences containing lexical main verbs were created in German. They had either 12 or 13 syllables (average $=12.5$ ) and eight words. All of these verbs ended in -en in the infinitive and in $-t$ in the finite conditions.

In French, two versions of the lexical verb materials were created: one with 16 verbs belonging to the most frequent verb group ending in -er, and one with 16 verbs ending in -ir or -re. As there was no difference between the results in the two versions of the experiment, they are collapsed in the following. ${ }^{10}$ The French sentences had between 11 and 13 syllables (11.875 on average) and between 8 and 10 words ( 8.5 on average). Lexical verbs appeared in four different conditions: finite verbs in raised and unraised positions and nonfinite verbs in raised and unraised position. Examples for all four conditions are given in Table 6.

Because it seems crucial in a memory-based task such as elicited imitation to maintain the same number of syllables across conditions, changes were made to the determiner or adjective in the later part of the sentences in those cases in which the nonfinite verb form had one syllable more than the finite verb form. For example, the French stimulus sentence Le capitaine marche pas dans les jolies collines ("The captain walk FIN not in the nice hills") was changed to Le capitaine marcher pas dans les belles collines ("The captain walk INF not in the beautiful hills") in the infinitival conditions, thus choosing a shorter adjective (monosyllabic belles instead of disyllabic jolies) to compensate for the longer verb form. Finally, 24 simple declarative present tense filler sentences were created in German and 24 for each of the two versions in French. Two-thirds of the filler sentences were 
grammatical and one-third contained word order and agreement errors, so that $50 \%$ of all sentences appearing in the experiment were grammatical. The filler sentences contained no negator. Across all materials, no lexical item occurred more than twice in the German materials, and more than twice in each version of the French experiment.

Items were recorded with a female native speaker of German and a female native speaker of French. The speakers were instructed to read the sentences in a natural way, but slowly. In particular, care was taken that all verb endings were clearly audible.

\section{Procedure}

Four experimental lists were created in which every auxiliary item appeared in one of the two possible conditions in two lists, respectively, and the lexical verb items appeared in a different one of the four possible conditions on each list. A given participant was always presented with all the items from one single list, so that each participants heard one version of each item only. The same randomized order was used in each list. To control for effects of order, reverse lists were used for half of the participants in which the second half of the original list was presented first. Note that the two French versions of the experiment differed only in the lexical verb items, whereas the same auxiliary items were used in both versions. Each of the two versions was presented to the learners of French either on different days or in two sessions separated by a break. Each version of the French experiment and the German experiment were split into two halves of 24 sentences each. In between these two halves, participants performed a range of other tasks. Each half of the experiment started with two warm-up sentences in both languages. Participants heard the sentences via headphones and were instructed to repeat each sentence. If they were unable to repeat a sentence, they could listen to it again until they were able to repeat it or decided to go over to the next sentence. All repetitions were recorded and transcribed.

\section{Coding}

A number of unclear cases was excluded from further analysis. This concerned two items in the French experiment that were excluded because the finite form of the verbs in question is homophonous with the past participle and therefore not unambiguously finite (the form /ecri/ of the verb écrire, and /ri/ of the verb rire). Moreover, 38 cases in German (3.3\% of all data) and 101 cases in French $(4.89 \%)$ were excluded because the recording was inaudible or participants introduced new elements or changed existing elements in the sentence so that coding was impossible. These changes were replacements of a lexical verb by a LV, or an LV by a lexical verb, use of another negator than nicht in German or pas in French, placement of the negator in a position not adjacent to the verb, or multiple repetitions of the negator or the verb in the sentence such that no clear order was determinable. In French, there were also cases that had to be excluded in the lexical verb conditions because learners introduced an element between the subject and the verb that was not present in the original sentence and sounded 
like an LV or a combination of an LV with a clitic pronoun. Finally, there were cases that had to be discarded because participants omitted the verb, the negator, or both. The number of these incomplete repetitions was clearly different for the different verb types: there were more omissions for auxiliary sentences than for lexical verb sentences, due to frequent omissions of the auxiliary itself. All in all, 151 incomplete repetitions occurred in the two LV conditions in German (19.66\% of all instances of these conditions) and 318 in French (23.11\%). There were $173(11.26 \%)$ incomplete repetitions in the remaining four lexical verb conditions in German and $240(8.72 \%)$ in the remaining four lexical verb conditions in French. For the remaining cases ( 789 cases in German and 1327 cases in French), verb forms were coded as finite, nonfinite or other, in the same way as in the production analysis, and the order of the verb with respect to the negator was determined.

\section{Analysis and predictions}

The focus of the analyses is on changes occurring during the experiment rather than on successful repetitions alone. Changes during repetition are considered to be more informative, as correct repetitions might be due to participants repeating the sentence verbatim without any reconstruction process. In contrast, changes presumably require the active use of grammatical knowledge. Three kinds of analyses were performed.

In a first syntactic analysis, only those repetitions were taken into account in which participants successfully reproduced the presented verb form. It was then determined how often they maintained the order of the verb and the negator, and how often they reversed the order when repeating the sentences. If for a given kind of verb form the rate of change was higher from one position into the other position than the other way around, it was concluded that the latter position is preferred for this kind of verb form. In a second morphological analysis, how often participants changed the morphological form of the verb for a given position was analyzed. If for a given position, the rate of change was higher from one type of verb form into another type of verb form than the other way around, it was concluded that the latter type of verb form is preferred for this position. It is a drawback of separate syntactic and morphological analyses that overall preferences for certain structures over others might go unnoticed, as one and the same structure can be constructed either by a syntactic or by a morphological change. Moreover, participants occasionally made simultaneous changes of syntax and morphology and these changes were not taken into account in the first two types of analysis. For these reasons, it was determined in a third combined analysis how often each target structure occurred in all changes made in the experiment. Note that as for LVs, participants only made syntactic changes and never changed the morphological form of the LV, the morphological and the combined analysis are restricted to the lexical verb items. The three analyses performed for lexical verbs are not independent of each other: as participants can choose to change sentences in multiple ways (syntactically, morphologically, or in both ways), the absence of changes of one type in a certain condition might be due to the high number of other kinds of changes in this condition. ${ }^{11}$ For this reason, no conclusions 
Table 7. Percentage of changes in verb placement when morphology is maintained in low-agr groups

\begin{tabular}{llr}
\hline \hline & \multicolumn{1}{c}{ German } & \multicolumn{1}{c}{ French } \\
\hline LV NEG $\rightarrow$ NEG LV & $1.89 \%(1 / 53)$ & $3.41 \%(3 / 88)$ \\
NEG LV $\rightarrow$ LV NEG & $33.33 \%(14 / 42)$ & $13.33 \%(8 / 60)$ \\
- FIN NEG $\rightarrow$ NEG -FIN & $23.26 \%(10 / 43)$ & $1.37 \%(1 / 73)$ \\
NEG - FIN $\rightarrow$-FIN NEG & $14.58 \%(7 / 48)$ & $0 \%(0 / 91)$ \\
+ FIN NEG $\rightarrow$ NEG +FIN & $11.76 \%(4 / 34)$ & $0 \%(0 / 89)$ \\
NEG +FIN $\rightarrow$ +FIN NEG & $18.18 \%(6 / 33)$ & $2.22 \%(2 / 90)$ \\
\hline \hline
\end{tabular}

can be drawn from the absence of one type of change alone. Rather, all three analyses are taken together in the following for interpreting the results in each group.

Both the SDH and the MSIH predict that if participants make changes to LVs, they should reveal a preference for a raised over an unraised position for this kind of verb. For nonfinite lexical verbs, neither of the theories predicts any specific preferences. Predictions differ for the behavior of finite lexical verbs, depending on whether finiteness (MSIH) or lightness (SDH) is assumed to be the driving factor for placing verbs in a raised position at early stages of development. The MSIH predicts that if changes occur for lexical finite verbs, they should reveal a preference for this verb type to appear in a raised position: if syntactic changes are made, finite lexical verbs should be more often changed from an unraised to a raised position than the other way around. If morphological changes are made, nonfinite verbs should be preferred over finite verbs in an unraised position. No corresponding predictions are made for the raised position, as both finite and nonfinite forms might be acceptable in this position due to the use of nonfinite forms as default forms. The overall pattern of changes should show that participants do not change sentences into utterances containing finite verbs in unraised positions, whereas changes to finite forms in raised positions and nonfinite forms in either position might occur.

In contrast, the SDH predicts that there should be no contingency between finiteness and placement preferences: if there are syntactic changes for lexical verbs, they should not differ for finite compared to nonfinite verbs. If there are morphological changes, they should not differ in the two positions. No particular utterance type is predicted to be absent from all changes involving lexical verbs that occur in the experiment. In the following, the results are presented separately for the two proficiency groups. ${ }^{12}$

\section{Results low-agr groups}

Table 7 shows the results of the syntactic analysis in the low-agr groups, that is, the number of changes in verb placement in each condition out of all cases in which the verb form was repeated as it had been presented.

As predicted by all approaches, there were significantly more changes from unraised to raised positions than from raised to unraised positions for auxiliary 
Table 8. Percentage of changes in morphology when verb placement is maintained in low-agr groups

\begin{tabular}{lcc}
\hline \hline & German & French \\
\hline +FIN NEG $\rightarrow$-FIN NEG & $11.76 \%(6 / 51)$ & $3 \%(3 / 100)$ \\
- FIN NEG $\rightarrow$ +FIN NEG & $6.67 \%(3 / 45)$ & $12.96 \%(14 / 109)$ \\
NEG +FIN $\rightarrow$ NEG - FIN & $9.52 \%(4 / 42)$ & $6.42 \%(7 / 109)$ \\
NEG - FIN $\rightarrow$ NEG +FIN & $2 \%(1 / 50)$ & $6.31 \%(7 / 111)$ \\
\hline \hline
\end{tabular}

verbs in both languages, $\chi^{2}(1)=17.4, p<.001$ for German, and $\chi^{2}(1)=4.82$, $p<.05$ for French. Examples for changes in auxiliary sentences are given in (15) for German and in (16) for French. Note that here as in the examples given in the following, learners also made other changes to the sentence than the ones investigated here, supporting the assumption that the sentence was not retained as a whole in memory and had to be reconstructed.

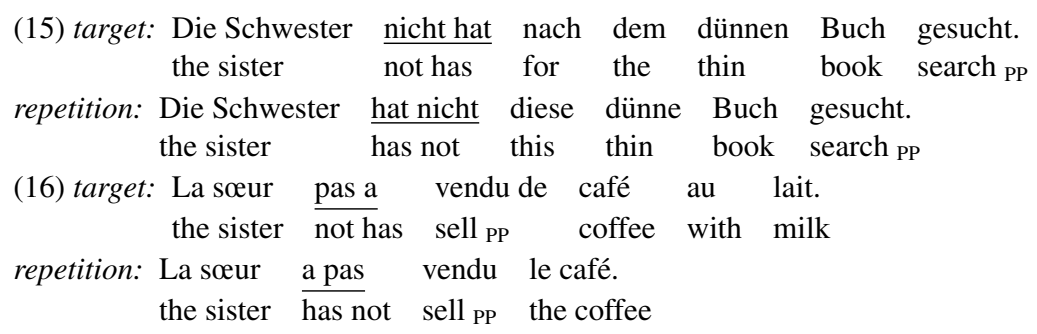

For nonfinite lexical verbs, the learners of German sometimes changed the position, but changes were not significantly more frequent in one direction than the other, $\chi^{2}$ $(1)=1.12, n s$. This is also in line with both the SDH and the MSIH. Unexpectedly for the MSIH, however, the same pattern holds for finite lexical verbs: there were changes in both direction, but no position was clearly preferred, $\chi^{2}(1)=0.54$, $n s$. The learners of French did not make a significant number of changes in the word order for lexical verbs at all. This finding will be taken up in the general discussion.

Table 8 shows how often participants changed the morphological form of a verb from finite to nonfinite or from nonfinite to finite in all repetitions in the lexical verb conditions in which the position of the verb was maintained.

In German, there is no evidence that any particular morphology is preferred in a certain position. Learners of French, however, prefer finite over nonfinite verbs in raised positions, $\chi^{2}(1)=6.66, p=.01$. In contrast, they do not prefer nonfinite over finite verbs in unraised positions, $\chi^{2}(1)=.001, n s$. An example for this preferred type of change is given in (17):

\begin{tabular}{|c|c|c|c|}
\hline (17) target: & $\begin{array}{l}\text { Le garçon } \\
\text { the boy }\end{array}$ & $\frac{\text { manger pas }}{\text { eat }_{\mathrm{INF}} \text { not }}$ & $\begin{array}{ll}\text { dans la vieille } \\
\text { in the old }\end{array}$ \\
\hline & $\begin{array}{l}\text { Le garçon } \\
\text { the boy }\end{array}$ & $\frac{\text { mange pas }}{\text { eat }_{\text {FIN }} \text { not }}$ & $\begin{array}{l}\text { la cuisine. } \\
\text { the kitchen }\end{array}$ \\
\hline
\end{tabular}


Table 9. Overview of all changes involving lexical verbs in low-agr groups: Absolute numbers

\begin{tabular}{lccrrr}
\hline \hline & \multicolumn{2}{c}{ German } & & \multicolumn{2}{c}{ French } \\
\cline { 2 - 3 } \cline { 5 - 6 } & V-Neg & Neg-V & & V-Neg & Neg-V \\
\hline -FIN & 16 & 17 & & 3 & 10 \\
+ FIN & 11 & 5 & & 16 & 8 \\
\hline \hline
\end{tabular}

Finally, Table 9 presents an overview of all changes that occurred for lexical verb items in the low-agr groups. These are all changes that have been displayed in Tables 7 and 8 in addition to occasional occurrences of changes of both syntax and morphology.

In German, the combined analysis shows that finite verbs in unraised positions are the least frequent pattern overall, but this effect is not strong enough to lead to a significant contingency of finiteness and verb placement, $\chi^{2}(1)=1.79, n s$. In contrast, this contingency is clearly present for the learners of French, $\chi^{2}(1)=$ $6.41, p=.01$. This, however, is not due to an avoidance of finite verbs in unraised position, as predicted by the MSIH. Rather, the effect in French is carried by a difference in preferences in the second position, where finite, but not nonfinite, verbs occur.

All in all, the results for LVs are in line with both hypotheses. The pattern of changes for lexical verbs in German is in line with the SDH, but not with the MSIH: learners made both syntactic and morphological changes, but no clear contingency between finiteness and verb raising could be observed for lexical verbs. In French, the lexical verb data are not in line with the SDH, as finite and nonfinite verbs are treated differently from each other. However, there seem to be more restrictions on the placement of nonfinite than of finite forms. Nonfinite forms were frequently changed to a finite form when they were presented in a raised position, whereas they were mostly maintained in unraised positions. No such difference between the two positions could be observed for finite forms, which were maintained in raised as well as unraised positions. This pattern of results is unexpected for the MSIH and is further discussed after the presentation of the results for the high-agr groups.

\section{Results high-agr groups}

The same analyses were applied as for the low-agr groups. Table 10 shows the results of the syntactic analysis, that is, the number of changes in word order out of all cases in which the morphology of the given verb was maintained.

It is not surprising that the placement of LVs in raised as opposed to unraised positions is preferred in the high-agr groups as it was in the low-agr groups, $\chi^{2}(1)=53.9, p<.001$ in German, and $\chi^{2}(1)=8.83, p<.005$ in French. In German, this preference for raised over unraised structures can also be observed for lexical verbs. However, this is true not only for finite lexical verbs, $\chi^{2}(1)=19.7$, 
Table 10. Percentage of changes in verb placement when morphology is maintained in high-agr groups

\begin{tabular}{lcc}
\hline \hline & German & French \\
\hline LV NEG $\rightarrow$ NEG LV & $1.52 \%(1 / 66)$ & $4.31 \%(5 / 116)$ \\
NEG LV $\rightarrow$ LV NEG & $60.94 \%(39 / 64)$ & $16.85 \%(15 / 89)$ \\
- FIN NEG $\rightarrow$ NEG - FIN & $13.56 \%(8 / 60)$ & $5.75 \%(5 / 87)$ \\
NEG - FIN $\rightarrow$-FIN NEG & $29.03 \%(18 / 62)$ & $0.91 \%(1 / 110)$ \\
+ FIN NEG $\rightarrow$ NEG +FIN & $5.66 \%(3 / 53)$ & $0.85 \%(1 / 118)$ \\
NEG +FIN $\rightarrow$ +FIN NEG & $42.11 \%(24 / 57)$ & $1.74 \%(2 / 115)$ \\
\hline \hline
\end{tabular}

Table 11. Percentage of changes in morphology when verb placement is maintained in high-agr groups

\begin{tabular}{lcc}
\hline \hline & German & French \\
\hline+ FIN NEG $\rightarrow$-FIN NEG & $1.45 \%(1 / 69)$ & $2.36 \%(3 / 127)$ \\
-FIN NEG $\rightarrow$ +FIN NEG & $13.89 \%(10 / 72)$ & $19.35 \%(24 / 124)$ \\
NEG +FIN $\rightarrow$ NEG -FIN & $13.33 \%(6 / 45)$ & $5.47 \%(7 / 128)$ \\
NEG - FIN $\rightarrow$ NEG +FIN & $7.69 \%(4 / 52)$ & $8.46 \%(11 / 130)$ \\
\hline \hline
\end{tabular}

$p<.001$, but also for nonfinite lexical verbs, $\chi^{2}(1)=4.87, p<.05$. In contrast, the rate of change for auxiliary verbs is significantly higher than the rate of change for finite lexical verbs, $\chi^{2}(1)=4.28, p<.05$. Examples for raising of both finite and nonfinite lexical verbs are given in (18) and (19), which present data from the same item, produced by different learners in different conditions:

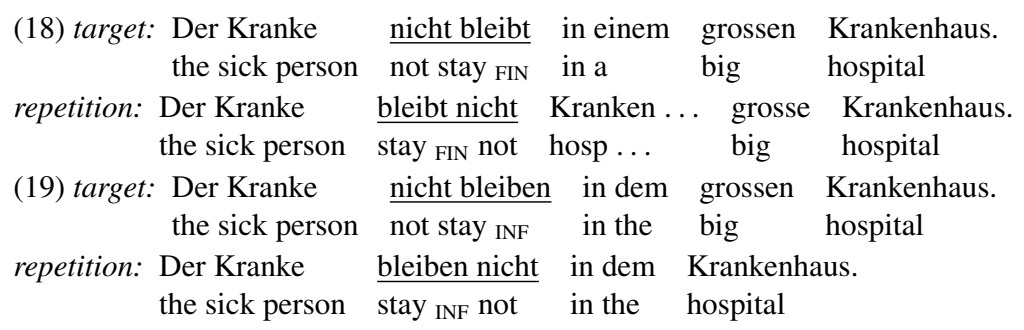

In French, there is again no substantial number of changes for the lexical verbs. The results for the morphological changes are summarized in Table 11.

The pattern for the learners of French is similar to the one observed in the lowagr group: participants prefer finite verbs over nonfinite verbs in raised positions, $\chi^{2}(1)=18.9, p<.001$, whereas there is no clear preference in unraised positions, $\chi^{2}(1)=0.89, n s$. The absence of a preference in the unraised position is not due to an absence of any changes in this position. Rather, as had also been the case in the low-agr group, participants made changes both from finite to nonfinite and 
Table 12. Changes to each of the target patterns in high-agr groups: Absolute numbers

\begin{tabular}{lccrrr}
\hline \hline & \multicolumn{2}{c}{ German } & & \multicolumn{2}{c}{ French } \\
\cline { 2 - 3 } \cline { 5 - 6 } & V-Neg & Neg-V & & V-Neg & Neg-V \\
\hline -FIN & 22 & 16 & & 4 & 15 \\
+ FIN & 44 & 7 & & 29 & 12 \\
\hline \hline
\end{tabular}

from nonfinite to finite forms. An example for the first type of change is given in (20), and for the second type of change in (21).

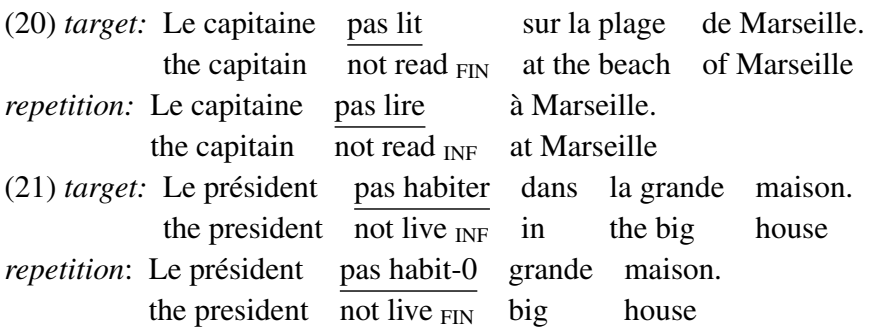

The same asymmetry can be observed in the learners of German: whereas finite forms are preferred over nonfinite forms in the raised position, $\chi^{2}(1)=7.58, p<$ .01 , there is no clear difference in the preferences for the unraised position, $\chi^{2}(1)=$ $0.83, n s$. An example for a change to a finite form in raised position is given in (22):

\begin{tabular}{|c|c|c|c|}
\hline (22) target & $\begin{array}{l}\text { Das Mädchen } \\
\text { the girl }\end{array}$ & $\frac{\text { gehen nicht }}{\text { go }_{\text {INF }} \text { not }}$ & $\begin{array}{l}\text { zu der alten } \\
\text { to the old }\end{array}$ \\
\hline tition & $\begin{array}{l}\text { Das Mädchen } \\
\text { the girl }\end{array}$ & $\frac{\text { geht nicht }}{\text { go FIN not }}$ & $\begin{array}{ll}\text { Ilte } & \text { Schule. } \\
\text { ld } & \text { school }\end{array}$ \\
\hline
\end{tabular}

Finally, Table 12 presents the combined analysis, the absolute numbers of all types of changes involving lexical verbs in the high-agr groups.

In both target languages there is a clear contingency between finiteness and verb placement in this overall rate of change, $\chi^{2}(1)=9.15, p<.01$ in German, and $\chi^{2}(1)=12.9, p<.001$ in French. In German, this is due to changes to finite verbs in unraised positions being very rare, whereas nonfinite forms can occur in both positions. The reversed pattern can be observed in French: changes into nonfinite forms in raised positions are very rare, whereas changes into finite verbs in unraised positions can occur similarly frequently as changes into nonfinite verbs in this position. All in all, data from both target languages confirm the contingency between finiteness and verb placement predicted by the MSIH, which is unexpected for the SDH. Deviations from this pattern, however, are frequent. 
As for deviations concerning nonfinite forms, it is striking that the more advanced learners of German changed these verb forms from an unraised to a raised position. This suggests that these participants prefer the raised position even for nonfinite verbs, which might indicate the use of nonfinite forms as default forms. It should be noted, however, that the morphological changes as well as the combined number of changes show that finite verbs are clearly preferred over nonfinite ones in this position by this group. Moroever, the homophony between infinitives and finite plural-marked forms in German might have fostered the use of seemingly nonfinite verb forms in second position in elicited imitation. In particular, it cannot be excluded that participants have wrongly analyzed the singular subject noun phrases of the presented sentences as plural subjects at least in some cases. To sum up, the cause of nonfinite forms in second position could either be their use as nonfinite default forms, or the wrong assumption that the subjects of the sentences were plural subjects. In both cases, the occurrence of nonfinite forms in this position is in line not only with the SDH but also with the MSIH.

In contrast, overuses of finite forms are unexpected under the MSIH. This more problematic type of deviation can be found in both target languages. In French, there is clear evidence that finite forms can be used in a nonfinite position: in contrast to auxiliary verbs, finite lexical verbs were not raised out of this position by learners of French. They were also not frequently changed to a nonfinite form. As discussed above, it is difficult to draw conclusions from the absence of changes in an imitation task. However, that participants changed nonfinite to finite forms in second position suggests that if they have morphological preferences, they are reflected in this task. This makes the absence of changes in the unraised position more telling than if no morphological changes had occurred in any position. In addition, the acceptability of finite forms in nonfinite positions is also reflected in the active changes from nonfinite to finite forms that participants sometimes made in this position. In German, the evidence is less clear: participants raised finite forms frequently if they were presented in an unraised position. This makes the absence of morphological changes less telling: if a relatively large percentage of the presented sentences in a condition is changed syntactically, there are less utterances left in which morphological preferences can show up. In contrast to the data in French, in which almost no syntactic changes occurred for lexical verbs, a direct comparison between morphological preferences in the raised position to those in the unraised position is therefore problematic in German. Note also that it is not expected that a pattern that is ungrammatical according to the L2 grammar should not be reproduced at all, as participants certainly can achieve a verbatim repetition of a presented sentence form even if this form is ungrammatical for them. However, it remains that an unraised position of finite lexical verbs provoked less syntactic changes than an unraised position of auxiliaries, and that this difference is not due to participants resorting to morphological changes instead. Note, incidentally, that this difference can also not be due to participants in the low-agr group being familiar with auxiliaries, but not with finite morphology on lexical verbs, as all but three learners in this group used finite morphology on lexical verbs at least once (see Appendix B1). The difference in the treatment of finite lexical verbs and auxiliaries can be explained when assuming that some of the correct repetitions of finite lexical verbs in unraised positions are due to a higher acceptability of this 
pattern compared to unraised auxiliaries at least for some learners in this group. This finding is taken up in the general discussion, in which results from both tasks are brought together and examined in light of the different theories.

\section{GENERAL DISCUSSION}

Taking all presented results together, finite lexical verbs clearly behave differently both from finite LVs and from nonfinite lexical verbs in both target languages and at both levels of proficiency. This is true for the semispontaneous production data, and was confirmed in the more controlled elicited imitation task. This pattern of results can be explained neither by the $\mathrm{SDH}$, which predicts finite lexical verbs to be as variable in their placement as nonfinite verbs, nor by the MSIH, which predicts finite lexical verbs to be placed as systematically as finite LVs. The results rather suggest that both finiteness and lightness play a role in verb placement, and that each of the two theories can account for part of the data only.

There are aspects of the data that are in line with the MSIH. There is evidence for a general contingency between finiteness and verb placement in all groups in semispontaneous production, and in all but the low-agr group in German in imitation. There is also evidence that exceptions from this contingency can occur due to the use of nonfinite verbs as default forms. In particular, the semispontaneous production results show that learners of German and French occasionally produced nonfinite instead of finite forms preceding the negator. In addition, the more proficient learners of German changed nonfinite verbs from an unraised to a raised position in the imitation task, which might also be taken to suggest that these forms are compatible with a raised position in the L2 grammar in German. ${ }^{13}$ Two aspects of the data cannot be explained by the MSIH, however. First, it is unexpected under the MSIH that there was no robust evidence for a relation between finiteness and verb placement in the low-agr group in German. These learners did not treat finite lexical verbs differently from nonfinite lexical verbs in imitation, whereas they made a difference between finite LVs and finite lexical verbs. Second, the MSIH cannot explain that even for the other three learner groups, the placement of finite lexical verbs was less consistent than the placement of LVs. In imitation, a difference between finite and nonfinite verbs was observed for these groups, which, however, was not in line with the predictions of the MSIH; whereas nonfinite forms were changed into finite forms in a raised position, finite forms were not changed into nonfinite forms in an unraised position. ${ }^{14}$ Moreover, finite verbs sometimes appeared after the negator in semispontaneous production. Taken together, these results ask for a description of the L2 grammar that can account for finite lexical verbs not being exclusively placed in a raised position. In the following, it is discussed which of the different remaining theories of L2 syntactic knowledge can account for the overall pattern of results, while also accommodating the occurrence of finite forms in unraised positions.

Consider first the idea that functional categories might be permanently absent from L2 grammars, as suggested by Meisel (1997). Under this assumption, the unsystematic placement of finite lexical forms is expected. Moreover, this theory need not be incompatible with the more consistent placement preferences for LVs, when it is combined with a semantic approach to LV placement. But although 
deviations from the target pattern can be explained, it is unclear why the pattern is present in the first place: why do learners show a preference for finite forms appearing in front of the negator, and nonfinite forms appearing after the negator? Meisel (1997) does not explain how learners are able to extract specifically this pattern from the input, while deviating from input patterns in many ways in their production as a whole. In particular, the contingency cannot be due to a simple learning mechanism according to which linear strings of lexical items that never appear in the input would be avoided. In German, plural verb forms can obviously occur before the negator, and these forms are homophonous to infinitives. On the other hand, finite forms can appear after the negator in subordinate clauses. As long as no more detailed mechanism is proposed which can account for the observed pattern, it has to be concluded that assuming a complete absence of hierarchical syntactic representation in L2 cannot explain the observed data as a whole. This also holds for those versions of a permanent impairment approach that do assume the existence of functional categories in L2 grammars (Beck, 1998; Eubank, 1993/1994). These approaches suppose that L2 grammars are characterized by a local impairment in verbal feature strength, such that L2 learners cannot determine whether their target language has strong or weak verbal features, and as a consequence, whether verb raising is obligatory or prohibited. This should then lead to verb raising being optional and independent of agreement. As put by Beck (1998): "The local impairment hypothesis . . . suggests . . that raising will always be divorced from any potential relationship to overt morphology" (p. 321). This is clearly not what was observed in the present data. It can be concluded that theories that assume a permanent validity of the SDH cannot account for the data observed here.

Other researchers apply the SDH only to a certain stage of L2 development, and assume that after an initial phase at which representations are not targetlike, L2 learners can build up nativelike representations, at least when certain conditions are met (Dimroth et al., 2003; Hawkins, 2001; Vainikka \& Young-Scholten, 1994, 1996a, 1996b). With respect to the relation between finiteness and verb placement, concrete predictions are only made by Vainikka and Young-Scholten, so that the comparison of the present data with the predictions are restricted to the claims of these authors in the following. ${ }^{15}$ Vainikka and Young-Scholten (1996a) describe the following stages in the acquisition of German as an L2: at a first stage, during which only a VP is projected, participants produce almost exclusively unraised structures. Moreover, they have not acquired an agreement paradigm and use nonfinite default forms. This then leads to unraised structures and nonfinite forms going together, which, however, does not mean that the relation between finiteness and verb placement has been acquired. Rather, the dominance of nonfinite verbs in unraised positions is due to neither verb raising nor subject-verb agreement having been acquired. At a following stage, the FP stage, a verbal functional projection is assumed to exist but to be not specifically tied to finiteness: verbs are raised independent of whether they are finite, as the agreement paradigm has not yet been acquired. Only at a last stage, the AgrP stage, should learners exclusively produce raised structures and finite verbs. Moreover, Vainikka and Young-Scholten assume that stages can coexist, such that the production of a learner at a given time point can mostly correspond to one stage, but occasionally shows signs of 
the next stage: "What we mean by, e.g., being at the $V$ - stage is that a VP-based grammar is the most robust one for the speaker; however, depending on the point in development that data collection took place, the grammar of the subsequent stage . . . may compete with the VP-grammar" (Vainikka \& Young-Scholten, 1996a, p. 13). Such gradual transitions between phases are also assumed in other stage models of development, as the one proposed by Dimroth et al. (2003). In the following, it is going to be argued that it is possible to account for the data of the present study by taking this structure-building approach.

Under this view, it seems that most participants of the low-agr group in German are at the VP stage, explaining why the majority of learners' utterances is composed of nonfinite verbs in an unraised position. The few instances of finite verbs in raised positions occurring in the production of this group might be unanalyzed chunks taken over from the input. This patterns well with the behavior of this group in the imitation task, where no evidence could be found for a relation between finiteness and placement for lexical verbs. That participants showed a preference for auxiliaries in raised positions would then strongly suggest that semantic factors constrain utterance structure in addition to purely grammatical constraints. If assuming instead that auxiliaries are consistently placed because they are carriers of finiteness (Parodi, 2000), it is difficult to explain why there are no consistent preferences for finite lexical verbs, even though these occur in learners' production. The placement preferences for auxiliaries also suggest that at least some participants can project an underspecified FP even at this stage, which provides the landing site for the auxiliaries and explains the few changes to raised structures in the imitation task. This is not unexpected for the structure-building approach. The data for the three remaining groups are on first sight more difficult to reconcile with this approach. In most of learners' semispontaneous production, if verb raising occurs, it does so for finite verbs, but not for nonfinite verbs. This suggests that these learners have already passed through the FP stage to an AgrP stage, at which verb raising is restricted to finite verbs. However, at the same time, nonfinite verbs in unraised positions constitute a frequent utterance pattern. This suggests that participants backslide frequently not only to the FP stage but also presumably even to the VP stage at which default forms are preferred over finite forms and unraised over raised structures. The coexistence of all three stages is neither explicitly excluded nor proposed by Vainikka and Young-Scholten (1996a). However, this scenario does not seem unlikely in cross-sectional studies as the present, in which collapsing data from learners in whom the different stages coexist, but to a different degree of dominance in different learners, might lead to properties of several stages showing up in the data of one proficiency group.

To sum up, structure-building accounts can explain the absence of a robust contingency between finiteness and verb placement at early stages, contrary to the MSIH, and at the same time explain the presence of this contingency at later stages, contrary to the SDH. Finite lexical verbs in unraised positions are an unexpected utterance pattern also for these accounts. There are several possible explanations, however, which are compatible with structure building. One possible explanation is that learners can backslide to an unraised utterance structure without necessarily also adapting the morphology to this structure. An alternative explanation would be that, as alluded to in the introductory section, forms that look finite on the surface 
might have a different status for the learner. Proponents of the MSIH have argued that this is not the case (Prévost \& White, 2000). However, in French, both the high frequency of finite forms in unraised structures in semispontaneous production (compared to nonfinite forms) and that nonfinite forms were frequently changed to finite forms in this position in imitation strongly suggest that these forms can be used as a default form in all contexts. The idea that the bare stem is a default form has been suggested before by Ferdinand (1996) for child French and Prévost (2004) for English learners of L2 French. However, Prévost (2004) suggested that English learners make this analysis because in English the infinitival forms correspond to the bare stem. This is not the case in Turkish, so that this use of finite forms should not occur in Turkish learners of French according to Prévost (2004). This prediction does not hold true for the present learner sample, suggesting that finite forms can be overused as default forms also by learners whose L1 has an open morphological infinitive marker. For German, there is less evidence that the finite forms investigated here, ending in $-t$, are used as default forms: although these forms occasionally appear in an unraised position, they do not constitute a similar proportion of verb forms in this position as the bare stem in French. It is conceivable, however, that forms ending in $-t$ might have an ambiguous character to some learners because of their resemblance to past participle forms, which likewise end in $-t$ very often. ${ }^{16}$ This might contribute to the occasional appearance of finite forms in unraised position in German semispontaneous production, and their acceptance in elicited imitation.

An overall characterization of the data would then be that the SDH, but not the MSIH, can correctly describe early developmental stages in the acquisition of German. The MSIH, but not the SDH, can account for a large portion of the data at later stages. However, contrary to the predictions of the MSIH, finite forms seem to be used as default forms in French, and in both languages, there is frequent backsliding to unraised structures that can go together with variable use of finite and nonfinite morphology. This configuration of findings can best to be accounted for by structure-building views.

In addition to the different choice of default forms, there are several other striking differences between the learners of German and French, which are not captured by either of the two hypotheses, and which will be discussed in the remainder of the paper. In particular, learners of French seem to develop not only a preference for finite forms, but also for finite positions relatively early in the acquisition process. It cannot, of course, be excluded that an earlier stage of development exists in French and might have been missed in the present data. The observation that the use of a raised position is more widespread and early in learners of French than in learners of German is not, however, unique to the present study: whereas numerous examples of unraised structures are given in studies of German as an L2, such as Vainikka and Young-Scholten (1994, 1996a, 1996b), there are much less examples in studies of learners of French (Giuliano, 2003; Herschensohn, 2001; Meisel, 1997; Rule \& Marsden, 2006). This crosslinguistic difference might be related to different properties of the input in the two target languages. Learners of German can find evidence for a clause-final position of verbs in the input, whereas learners of French rarely find such input. This is first due to the different word order in subordinate clauses, in which verbs appear 
clause-finally in German but in second position in French. In addition, (nonfinite) lexical verbs also appear more often clause-finally in main clauses containing LV constructions in German than in French, due to the different headedness of the VP, which is head-initial in French but head-final in German. Learners of German thus receive inconsistent input: the verb sometimes appears in second and sometimes in final position. Given these two options, it seems plausible that in particular Turkish learners of German develop a preference for the final position, which corresponds to the position of the verb in Turkish. Moreover, this would be in accordance with a grammar in which only a (head-final) VP is postulated. In contrast, Turkish learners of French never receive any supportive evidence from the input that would encourage them in placing the verb in a clause-final position. The more consistent input might push learners to adopt a raised position for the verb earlier in the acquisition process when compared to the learners of German. One might wonder, however, how far this adoption of a raised position reflects the acquisition of "more nativelike" grammatical knowledge in the learners of French. The results of the semispontaneous production task as well as of the morphological analysis of the imitation task seem to suggest that verb raising is well established early in the acquisition process and also restricted to finite verbs relatively early, suggesting the development of a nativelike functional category for the learners of French. But the results of the syntactic analysis show that there seems to be a remarkable optionality between raised and unraised structures, as evidenced by the absence of syntactic changes for lexical verbs even in the high-agr group: these learners might rarely spontaneously produce unraised structures, for which no support is available in the input, but when confronted with this type of structure, they accept it and do not change it to a raised structure. This is in striking contrast to the learners of German, who do make syntactic changes. The behavior of the low-agr group in German suggests that learners of German acquire verb raising only after a longer phase without raising of lexical verbs. However, as soon as verb raising is acquired, as in the high-agr group, learners make a high number of changes from unraised to raised structures in imitation. Contrary to the learners of French, these learners had to overcome the competing unraised structures. Once this is achieved, the resulting grammatical knowledge seems to be stronger established than in learners who did not have to overcome a competing structure.

The strong cross-linguistic differences found in this study remind us that although general language-independent theories such as the SDH and the MSIH might capture important aspects of the acquisition process (at least for certain stages), they necessarily fail to take into account all aspects of this process for specific source- and target-language combinations. In particular, the data show that even target languages that seemingly present the same acquisition problem to learners (a contingency between finiteness and verb raising) can lead to different learning paths in dependency of other properties, such as the presence of alternative word orders in the input. Future research could investigate more specifically the influence of both surface and underlying syntactic similarities between source and target languages. The present study has confirmed that elicited imitation can be a useful tool for detecting grammatical preferences, and it could be applied to the testing of structures with a varying degree of similarity between source and target languages in the future. 
Moreover, the task could also be used in longitudinal case studies, where highly comparable data with the same learner(s) at different points of development could be elicited. Data of this type might allow for a more fine-grained description of syntactic development than is possible in a study that collapses data from different learners who might be at slightly different levels of proficiency, and would therefore constitute an important complement to cross-sectional studies as the present.

\section{APPENDIX A}

Table A.1. Information about learners of German ${ }^{a}$

\begin{tabular}{|c|c|c|c|c|c|c|}
\hline Ppt. Nbr. & Sex & Age & Residence & $\mathrm{AoO}$ & Instruction & Contact \\
\hline 48 & M & 45 & $2 ; 6$ & 43 & 3 & $\mathrm{R}$ \\
\hline 72 & $\mathrm{~F}$ & 23 & $2 ; 3$ & 21 & 5 & NA \\
\hline 73 & $\mathrm{~F}$ & 17 & $0 ; 6$ & 17 & 2 & 0 \\
\hline 17 & $\mathrm{~F}$ & 27 & $6 ; 8$ & 20 & 0 & $\mathrm{~L}$ \\
\hline 45 & $\mathrm{~F}$ & 35 & $17 ; 0$ & 18 & 13 & $\mathrm{R}$ \\
\hline 42 & $\mathrm{M}$ & 34 & $9 ; 0$ & 25 & 2 & $\mathrm{R}$ \\
\hline 57 & $\mathrm{~F}$ & 27 & $11 ; 0$ & 16 & 3 & $\mathrm{~L}$ \\
\hline 39 & $\mathrm{M}$ & 31 & $4 ; 0$ & 27 & 1 & $\mathrm{~L}$ \\
\hline 71 & $\mathrm{M}$ & 38 & $2 ; 3$ & 36 & 7 & $\mathrm{~L}$ \\
\hline 62 & $\mathrm{M}$ & 40 & $17 ; 0$ & 23 & 9 & $\mathrm{R}$ \\
\hline 12 & $\mathrm{~F}$ & 32 & $13 ; 0$ & 19 & 6 & $\mathrm{~L}$ \\
\hline 53 & $\mathrm{~F}$ & 40 & $4 ; 0$ & 36 & 1 & $\mathrm{R}$ \\
\hline 44 & $\mathrm{~F}$ & 38 & $6 ; 0$ & 32 & 3 & $\mathrm{R}$ \\
\hline 20 & $\mathrm{M}$ & 27 & $2 ; 3$ & 25 & 0 & $\mathrm{~L}$ \\
\hline 40 & $\mathrm{~F}$ & 29 & $4 ; 0$ & 25 & 12 & $\mathrm{~L}$ \\
\hline 51 & $\mathrm{~F}$ & 26 & $8 ; 0$ & 18 & 6 & $\bar{L}$ \\
\hline 11 & $\mathrm{~F}$ & 48 & $25 ; 0$ & 23 & 12 & $(\mathrm{R})$ \\
\hline 43 & $\mathrm{~F}$ & 35 & $21 ; 0$ & 14 & 0 & (R) \\
\hline 33 & M & 51 & $17 ; 9$ & 33 & 3 & $\mathrm{~L}$ \\
\hline 55 & $\mathrm{M}$ & 23 & $2 ; 0$ & 21 & 4 & $\mathrm{R}$ \\
\hline 31 & $\mathrm{M}$ & 29 & $1 ; 0$ & 28 & 7 & $\mathrm{R}$ \\
\hline 26 & $\mathrm{M}$ & 23 & $2 ; 0$ & 21 & 4 & $\mathrm{R}$ \\
\hline 61 & $\mathrm{~F}$ & 29 & $8 ; 0$ & 21 & 2 & $\mathrm{R}$ \\
\hline 52 & $\mathrm{M}$ & 43 & $12 ; 0$ & 31 & 5 & $\mathrm{R}$ \\
\hline 47 & $\mathrm{~F}$ & 28 & $10 ; 0$ & 18 & 2 & $\mathrm{~L}$ \\
\hline 49 & $\mathrm{M}$ & 25 & $5 ; 0$ & 20 & 4 & $\mathrm{~L}$ \\
\hline 69 & $\mathrm{~F}$ & 36 & $2 ; 3$ & 34 & 6 & $\mathrm{~L}$ \\
\hline 32 & $\mathrm{M}$ & 29 & $6 ; 0$ & 23 & 5 & $\mathrm{R}$ \\
\hline 34 & $\mathrm{~F}$ & 37 & $19 ; 0$ & 18 & 1 & (R) \\
\hline 37 & $\mathrm{~F}$ & 36 & $15 ; 9$ & 20 & 6 & L \\
\hline 67 & $\mathrm{~F}$ & 32 & $12 ; 0$ & 20 & 12 & $\mathrm{~L}$ \\
\hline 58 & $\mathrm{M}$ & 41 & $4 ; 8$ & 36 & 15 & $\mathrm{~L}$ \\
\hline 22 & $\mathrm{~F}$ & 24 & $4 ; 0$ & 20 & 6 & $\mathrm{~L}$ \\
\hline 66 & $\mathrm{M}$ & 28 & $6 ; 0$ & 22 & 3 & $\mathrm{~L}$ \\
\hline
\end{tabular}


Table A.1 (cont.)

\begin{tabular}{|c|c|c|c|c|c|c|}
\hline Ppt. Nbr. & Sex & Age & Residence & $\mathrm{AoO}$ & Instruction & Contact \\
\hline 24 & $\mathrm{~F}$ & 37 & $18 ; 0$ & 19 & 3 & $\mathrm{~L}$ \\
\hline 70 & $\mathrm{~F}$ & 43 & $2 ; 3$ & 41 & 17 & $\mathrm{~L}$ \\
\hline 63 & $\mathrm{~F}$ & 31 & $10 ; 0$ & 21 & 2 & $\mathrm{~L}$ \\
\hline 64 & $\mathrm{M}$ & 44 & $15 ; 0$ & 29 & 7 & $\mathrm{R}$ \\
\hline 27 & $\mathrm{~F}$ & 29 & $6 ; 0$ & 23 & 2 & $\mathrm{~L}$ \\
\hline 41 & $\mathrm{~F}$ & 27 & $10 ; 0$ & 17 & 7 & $\mathrm{R}$ \\
\hline 30 & $\mathrm{~F}$ & 34 & $14 ; 1$ & 20 & 9 & $\mathrm{~L}$ \\
\hline 14 & $\mathrm{~F}$ & 31 & $4 ; 0$ & 27 & 24 & (R) \\
\hline 25 & $\mathrm{M}$ & 32 & $1 ; 11$ & 30 & 7 & $\mathrm{~L}$ \\
\hline 29 & $\mathrm{~F}$ & 29 & $10 ; 7$ & 19 & 4 & $\mathrm{R}$ \\
\hline 18 & $\mathrm{~F}$ & 28 & $8 ; 8$ & 19 & 6 & $\mathrm{~L}$ \\
\hline 23 & $\mathrm{M}$ & 48 & $14 ; 0$ & 34 & 7 & $\mathrm{R}$ \\
\hline 36 & $\mathrm{~F}$ & 29 & $11 ; 0$ & 18 & 16 & $\mathrm{R}$ \\
\hline 59 & F & 45 & $25 ; 0$ & 20 & 7 & $\mathrm{R}$ \\
\hline
\end{tabular}

Note: This table indicates for each participating learner of German the participant number (Ppt. Nbr.), sex, age (years), time of residence in Germany (years;months), age of onset (AoO) of the target language exposure (years), time in language course (months), and the intensity of contact with the target language ( $R$, regular contact, in particular due to work in a German-speaking environment; L, little contact; NA, information is not available). Note that all participants, even those with regular contact with the target language, continued to use Turkish on a daily basis. Moreover, the intensity of contact was asked for with respect to the moment of data collection and need not have been stable during the entire time span of residence. When regular contact was known to be very recent, it is indicated in parenthesis. The time of residence was only indicated in full years by many of the learners of German. These data are thus less accurate than for the learners of French. The intensity of instruction varied between learners; typical exposure was around $15 \mathrm{hr} /$ week.

${ }^{a}$ Eight learners of German were bilingual speakers of Turkish and Kurdish and two learners of German were bilingual speakers of Turkish and Arabic. All of these bilingual speakers reported Turkish to be their dominant language and in many cases the only language they were still actively using. There was also one learner of German who reported having acquired high proficiency in Azerbaijani and Russian as second languages. All of the remaining participants had none or very limited knowledge of another second language. For three of the learners (numbers 44, 57, and 69), only part of the retellings could be analyzed because of technical problems during recording. 
Schimke: Variable verb placement

Table A.2. Information about learners of French ${ }^{a}$

\begin{tabular}{|c|c|c|c|c|c|c|}
\hline Ppt. Nbr. & Sex & Age & Residence & AoO & Instruction & Contact \\
\hline 128 & $\mathrm{~F}$ & 49 & $20 ; 5$ & 29 & 6 & $\mathrm{~L}$ \\
\hline 142 & $\mathrm{~F}$ & 35 & $0 ; 9$ & 34 & 5 & $\mathrm{~L}$ \\
\hline 123 & $\mathrm{M}$ & 24 & $1 ; 1$ & 23 & 1 & $\mathrm{~L}$ \\
\hline 107 & $\mathrm{~F}$ & 44 & $26 ; 0$ & 18 & 4 & $\mathrm{~L}$ \\
\hline 146 & $\mathrm{~F}$ & 36 & $1 ; 5$ & 35 & 16 & $\mathrm{~L}$ \\
\hline 118 & $\mathrm{~F}$ & 36 & $5 ; 2$ & 31 & 20 & $\mathrm{~L}$ \\
\hline 132 & M & 27 & $0 ; 7$ & 26 & 3 & $\mathrm{~L}$ \\
\hline 144 & $\mathrm{~F}$ & 28 & $10 ; 0$ & 18 & 4 & $\mathrm{R}$ \\
\hline 109 & $\mathrm{~F}$ & 39 & $17 ; 10$ & 21 & 8 & $\mathrm{R}$ \\
\hline 117 & $\mathrm{~F}$ & 28 & $5 ; 5$ & 23 & 6 & $\mathrm{~L}$ \\
\hline 103 & $\mathrm{~F}$ & 30 & $5 ; 3$ & 25 & 3 & $\mathrm{R}$ \\
\hline 124 & $\mathrm{~F}$ & 37 & $4 ; 5$ & 33 & 48 & $\mathrm{~L}$ \\
\hline 104 & $\mathrm{M}$ & 47 & $24 ; 0$ & 23 & 3 & $\mathrm{R}$ \\
\hline 127 & $\mathrm{~F}$ & 34 & $8 ; 9$ & 25 & 17 & $\mathrm{~L}$ \\
\hline 108 & $\mathrm{~F}$ & 38 & $15 ; 3$ & 23 & 15 & $\mathrm{R}$ \\
\hline 101 & $\mathrm{~F}$ & 38 & $13 ; 4$ & 25 & 7 & $\mathrm{~L}$ \\
\hline 106 & $\mathrm{~F}$ & 26 & $0 ; 10$ & 25 & 5 & $\mathrm{~L}$ \\
\hline 129 & $\mathrm{~F}$ & 43 & $5 ; 7$ & 37 & 24 & $\mathrm{R}$ \\
\hline 141 & $\mathrm{~F}$ & 27 & $5 ; 9$ & 21 & 3 & $\mathrm{~L}$ \\
\hline 134 & M & 22 & $1 ; 0$ & 21 & 2 & $\mathrm{~L}$ \\
\hline 139 & $\mathrm{~F}$ & 42 & $1 ; 6$ & 40 & 6 & $\mathrm{~L}$ \\
\hline 105 & $\mathrm{~F}$ & 41 & $0 ; 9$ & 40 & 4 & $\bar{L}$ \\
\hline 116 & $\mathrm{~F}$ & 32 & $0 ; 8$ & 31 & 7 & $\mathrm{~L}$ \\
\hline 121 & $\mathrm{~F}$ & 48 & $23 ; 0$ & 25 & 6 & $\mathrm{~L}$ \\
\hline 136 & $\mathrm{M}$ & 27 & $0 ; 2$ & 27 & 2 & $\mathrm{R}$ \\
\hline 112 & $\mathrm{M}$ & 30 & $0 ; 6$ & 29 & 1 & $\mathrm{~L}$ \\
\hline 131 & $\mathrm{M}$ & 37 & $7 ; 7$ & 35 & 3 & $\mathrm{R}$ \\
\hline 113 & $\mathrm{M}$ & 49 & $23 ; 0$ & 26 & 3 & $\mathrm{~L}$ \\
\hline 120 & $\mathrm{~F}$ & 30 & $8 ; 0$ & 22 & 9 & $\mathrm{~L}$ \\
\hline 102 & $\mathrm{M}$ & 45 & $12 ; 10$ & 32 & 0 & $\mathrm{R}$ \\
\hline 119 & $\mathrm{~F}$ & 35 & $17 ; 0$ & 18 & 7 & $\mathrm{R}$ \\
\hline 125 & $\mathrm{M}$ & 24 & $2 ; 2$ & 22 & 0 & $\mathrm{R}$ \\
\hline 145 & $\mathrm{~F}$ & 22 & $1 ; 8$ & 20 & 4 & $\mathrm{R}$ \\
\hline 130 & $\mathrm{M}$ & 31 & $6 ; 8$ & 24 & 7 & $\mathrm{R}$ \\
\hline 140 & $\mathrm{~F}$ & 38 & $8 ; 6$ & 29 & 36 & $\mathrm{~L}$ \\
\hline 148 & $\mathrm{M}$ & 46 & $19 ; 10$ & 26 & 4 & $\mathrm{R}$ \\
\hline 126 & $\mathrm{~F}$ & 37 & $10 ; 0$ & 27 & 3 & $\mathrm{~L}$ \\
\hline 110 & $\mathrm{~F}$ & 31 & $5 ; 7$ & 25 & 48 & $\mathrm{R}$ \\
\hline 111 & $\mathrm{~F}$ & 49 & $23 ; 4$ & 26 & 20 & $\mathrm{~L}$ \\
\hline 147 & $\mathrm{~F}$ & 21 & $1 ; 11$ & 19 & 18 & $\mathrm{R}$ \\
\hline 138 & $\mathrm{M}$ & 25 & $2 ; 2$ & 23 & 1 & $\mathrm{R}$ \\
\hline
\end{tabular}


Schimke: Variable verb placement

Table A.2 (cont.)

\begin{tabular}{ccccccc}
\hline \hline Ppt. Nbr. & Sex & Age & Residence & AoO & Instruction & Contact \\
\hline 137 & $\mathrm{M}$ & 22 & $1 ; 8$ & 20 & 3 & $\mathrm{R}$ \\
133 & $\mathrm{M}$ & 18 & $1 ; 6$ & 16 & 1 & $\mathrm{R}$ \\
\hline \hline
\end{tabular}

Note: This table indicates for each participating learner of French the participant number (Ppt. Nbr.), sex, age (years), time of residence in France (years;months), age of onset (AoO) of the target language exposure (years), time in language course (months), and the intensity of contact with the target language ( $\mathrm{R}$, regular contact, in particular due to work in a French-speaking environment; L, little contact). Note that all participants, even those with regular contact with the target language, continued to use Turkish on a daily basis. Moreover, the intensity of contact was asked for with respect to the moment of data collection and need not have been stable during the entire time span of residence. The intensity of instruction varied between learners; typical exposure was around $15 \mathrm{hr} /$ week. ${ }^{a}$ Twelve learners of French were bilingual speakers of Turkish and Kurdish, one learner was a bilingual speakers of Turkish and Arabic, and two learners were bilingual speakers of Turkish and Armenian. All of these bilingual speakers reported Turkish to be their dominant language and in many cases the only language they were still actively using. All learners of French had none or very limited knowledge of second languages other than French. Note also that for two of the learners of French (numbers 119 and 127), only part of the retellings could be analyzed because of technical problems during recording.

\section{APPENDIX B}

Table B.1. Finiteness in semispontaneous production in German: Individual data

\begin{tabular}{|c|c|c|c|c|c|c|c|c|}
\hline $\begin{array}{l}\text { Ppt. } \\
\text { Nbr. }\end{array}$ & $\begin{array}{c}+ \text { FIN } \\
\text { Total }\end{array}$ & $\begin{aligned} & \% \\
+ & \text { FIN }\end{aligned}$ & $\begin{array}{c}\text { LV } \\
\text { Neg }\end{array}$ & $\begin{array}{l}\text { Neg } \\
\text { LV }\end{array}$ & $\begin{array}{c}- \text { FIN } \\
\text { Neg }\end{array}$ & $\begin{array}{l}\text { Neg } \\
\text {-FIN }\end{array}$ & $\begin{array}{c}+ \text { FIN } \\
\text { Neg }\end{array}$ & $\begin{array}{l}\text { Neg } \\
+ \text { FIN }\end{array}$ \\
\hline 48 & $0 / 24$ & 0.00 & & & & & & \\
\hline 72 & $0 / 26$ & 0.00 & & & & 4 & & \\
\hline 73 & $0 / 24$ & 0.00 & & & & & & \\
\hline 17 & $1 / 38$ & 2.63 & & & & & & \\
\hline 45 & $2 / 43$ & 4.65 & & & & 5 & & \\
\hline 42 & $2 / 42$ & 4.76 & & & & 1 & 1 & \\
\hline 57 & $1 / 15$ & 6.67 & & & & & 1 & \\
\hline 39 & $2 / 27$ & 7.41 & & & & 1 & & \\
\hline 71 & $2 / 22$ & 9.09 & & & & 1 & & \\
\hline 62 & $4 / 41$ & 9.76 & & & 1 & 1 & & \\
\hline 12 & $6 / 53$ & 11.32 & & & & 2 & & \\
\hline 53 & $5 / 37$ & 13.51 & & & & & & \\
\hline 44 & $3 / 19$ & 15.79 & & & & 2 & & \\
\hline 20 & $5 / 31$ & 16.13 & & 1 & & 2 & & \\
\hline 40 & $6 / 37$ & 16.22 & & & & & & \\
\hline 51 & $7 / 40$ & 17.50 & 1 & & & 4 & & \\
\hline 11 & $10 / 53$ & 18.87 & 2 & & & 1 & 1 & \\
\hline
\end{tabular}


Table B.1 (cont.)

\begin{tabular}{|c|c|c|c|c|c|c|c|c|}
\hline $\begin{array}{l}\text { Ppt. } \\
\text { Nbr. }\end{array}$ & $\begin{array}{c}+ \text { FIN } \\
\text { Total }\end{array}$ & $\begin{aligned} & \% \\
+ & \text { FIN }\end{aligned}$ & $\begin{array}{l}\text { LV } \\
\text { Neg }\end{array}$ & $\begin{array}{l}\text { Neg } \\
\text { LV }\end{array}$ & $\begin{array}{c}-\mathrm{FIN} \\
\mathrm{Neg}\end{array}$ & $\begin{array}{l}\mathrm{Neg} \\
\text {-FIN }\end{array}$ & $\begin{array}{c}+\mathrm{FIN} \\
\mathrm{Neg}\end{array}$ & $\begin{array}{l}\text { Neg } \\
\text { +FIN }\end{array}$ \\
\hline 43 & $7 / 37$ & 18.92 & & & & 3 & & \\
\hline 33 & $13 / 65$ & 20.00 & & & & 3 & 1 & \\
\hline 55 & $6 / 28$ & 21.43 & & & & 1 & 1 & \\
\hline 31 & $5 / 19$ & 26.32 & 1 & & & & & \\
\hline 26 & $14 / 49$ & 28.57 & & & 1 & 2 & & 1 \\
\hline 61 & $12 / 38$ & 31.58 & & & & 1 & & 1 \\
\hline 52 & $16 / 50$ & 32.00 & & & & 2 & & \\
\hline 47 & $11 / 34$ & 32.35 & 3 & & & 1 & & \\
\hline 49 & $9 / 27$ & 33.33 & & & & & & \\
\hline 69 & $4 / 11$ & 36.36 & 3 & & & 2 & & \\
\hline 32 & $11 / 30$ & 36.67 & & & & & 1 & \\
\hline 34 & $16 / 43$ & 37.21 & 1 & & & 1 & & \\
\hline 37 & $22 / 56$ & 39.29 & & & & 2 & & \\
\hline 67 & $25 / 63$ & 39.68 & 1 & & 1 & 2 & & 2 \\
\hline 58 & $18 / 41$ & 43.90 & & & & 2 & & \\
\hline 22 & $21 / 46$ & 45.65 & 4 & & & 2 & & \\
\hline 66 & $17 / 36$ & 47.22 & 1 & & & & 1 & \\
\hline 24 & $22 / 43$ & 51.16 & & & & 1 & & \\
\hline 70 & $18 / 35$ & 51.43 & 1 & & & 1 & & 1 \\
\hline 63 & $17 / 32$ & 53.13 & 2 & & & 2 & & \\
\hline 64 & $29 / 53$ & 54.72 & 3 & & & 1 & & 1 \\
\hline 27 & $29 / 52$ & 55.77 & & & & 1 & & \\
\hline 41 & $24 / 43$ & 55.81 & 3 & & & & & \\
\hline 30 & $27 / 45$ & 60.00 & 3 & & & & 1 & \\
\hline 14 & $19 / 27$ & 70.37 & 5 & & & 1 & 1 & \\
\hline 25 & $47 / 65$ & 72.31 & 6 & & & 2 & & 1 \\
\hline 29 & $18 / 23$ & 78.26 & 1 & & & & & \\
\hline 18 & $22 / 28$ & 78.57 & & & & & & \\
\hline 23 & $42 / 52$ & 80.77 & 2 & & & 1 & 4 & \\
\hline 36 & $42 / 49$ & 85.71 & 3 & & & & 1 & \\
\hline 59 & $33 / 35$ & 94.29 & 3 & & & & 1 & \\
\hline
\end{tabular}

Note: Each participant's total number of correctly agreeing verbs out of all lexical verbs in third singular contexts, the corresponding percentage, and the frequency of each of the negated utterance types discussed in the text: light verbs (LV) and nonfinite lexical $(-$ FIN) and finite lexical (+FIN) verbs following and preceding negation (neg). A blank cell indicates that a certain utterance type did not occur. 
Schimke: Variable verb placement

Table B.2. Finiteness in semispontaneous production in French: Individual data

\begin{tabular}{|c|c|c|c|c|c|c|c|c|}
\hline $\begin{array}{l}\text { Ppt. } \\
\text { Nbr. }\end{array}$ & $\begin{array}{l}+ \text { FIN } \\
/ \text { Total }\end{array}$ & $\begin{aligned} & \% \\
+ & \text { FIN }\end{aligned}$ & $\begin{array}{c}\text { LV } \\
\text { Neg }\end{array}$ & $\begin{array}{l}\text { Neg } \\
\text { LV }\end{array}$ & $\begin{array}{c}-\mathrm{FIN} \\
\text { Neg }\end{array}$ & $\begin{array}{c}\mathrm{Neg} \\
- \text { FIN }\end{array}$ & $\begin{array}{c}+ \text { FIN } \\
\text { Neg }\end{array}$ & $\begin{array}{c}\text { Neg } \\
+ \text { FIN }\end{array}$ \\
\hline 128 & $1 / 42$ & 2.38 & & & & 1 & 1 & \\
\hline 142 & $1 / 8$ & 12.50 & & & & & & \\
\hline 123 & $2 / 10$ & 20.00 & 3 & & & 1 & 1 & \\
\hline 107 & $7 / 31$ & 22.58 & 1 & & & & & \\
\hline 146 & $6 / 25$ & 24.00 & & & 4 & & & \\
\hline 118 & $9 / 33$ & 27.27 & & & 1 & & & \\
\hline 132 & $6 / 19$ & 31.58 & & & & & & \\
\hline 144 & $6 / 18$ & 33.33 & & & & & & \\
\hline 109 & $18 / 53$ & 33.96 & 1 & & & 1 & 2 & \\
\hline 117 & $14 / 40$ & 35.00 & 1 & & & & 1 & \\
\hline 103 & $9 / 24$ & 37.50 & 1 & & & & & 2 \\
\hline 124 & $9 / 23$ & 39.13 & & & & & & \\
\hline 104 & $12 / 29$ & 41.38 & 7 & & & & 1 & \\
\hline 127 & $11 / 26$ & 42.31 & 4 & & & 1 & & \\
\hline 108 & $14 / 33$ & 42.42 & & & & & 4 & \\
\hline 101 & $17 / 39$ & 43.59 & 3 & & 1 & 1 & 5 & \\
\hline 106 & $11 / 23$ & 47.83 & & & & & 1 & \\
\hline 141 & $12 / 24$ & 50.00 & 4 & & & & & \\
\hline 129 & $11 / 22$ & 50.00 & 3 & & & & 1 & \\
\hline 134 & $13 / 22$ & 59.09 & & & & & 3 & \\
\hline 139 & $25 / 42$ & 59.52 & 1 & & & & & 2 \\
\hline 105 & $12 / 20$ & 60.00 & 2 & & & & & \\
\hline 116 & $13 / 21$ & 61.90 & 4 & & & & & \\
\hline 121 & $28 / 44$ & 63.64 & 3 & & & 1 & 2 & \\
\hline 136 & $13 / 20$ & 65.00 & 1 & & & 2 & & 3 \\
\hline 131 & $19 / 29$ & 65.52 & & & & & 1 & \\
\hline 112 & $19 / 29$ & 65.52 & & & & & & \\
\hline 113 & $8 / 12$ & 66.67 & 6 & & & & 1 & \\
\hline 120 & $16 / 24$ & 66.67 & 2 & & & & & \\
\hline 102 & $22 / 32$ & 69.70 & 7 & & & & & \\
\hline 119 & $21 / 29$ & 72.41 & & & & & & \\
\hline 125 & $11 / 15$ & 73.33 & & & & & & \\
\hline 145 & $31 / 42$ & 73.81 & 2 & & & 2 & 2 & \\
\hline 148 & $8 / 10$ & 77.50 & 2 & & & & & \\
\hline 140 & $12 / 15$ & 80.00 & & & & & 1 & \\
\hline 130 & $32 / 40$ & 80.00 & & & & & & \\
\hline 126 & $23 / 28$ & 82.14 & 1 & & & & 3 & \\
\hline 110 & $34 / 41$ & 82.93 & & 1 & & 1 & & \\
\hline 111 & $38 / 44$ & 86.36 & 6 & & & & 1 & \\
\hline 147 & $35 / 40$ & 87.50 & 2 & & & & & \\
\hline 138 & $10 / 11$ & 90.91 & 3 & & & & 1 & \\
\hline 137 & $32 / 34$ & 94.12 & 3 & & & & & \\
\hline 133 & $28 / 28$ & 100.00 & 2 & & & & & \\
\hline
\end{tabular}

Note: Each participant's total number of correctly agreeing verbs out of all lexical verbs in third singular contexts, the corresponding percentage, and the frequency of each of the negated utterance types discussed in the text: light verbs (LV) and nonfinite lexical (-FIN) and finite lexical (+FIN) verbs following and preceding negation (neg). A blank cell indicates that a certain utterance type did not occur. 


\section{APPENDIX C}

Table C.1. Light verb materials for German

1. Die Mutter hat nicht über den dummen Film gelacht. The mother has not laughed about the stupid movie.

2. Der Bäcker hat nicht mit der hübschen Frau geredet. The baker has not talked to the pretty woman.

3. Der Koch hat nicht in dem neuen Haus gearbeitet. The cook has not worked in the new house.

4. Der Nachbar hat nicht mit dem braven Hund gespielt. The neighbor has not played with the friendly dog.

5. Der Student hat nicht nach der falschen Antwort gefragt. The student has not asked for the wrong answer.

6. Die Schwester hat nicht nach dem dünnen Buch gesucht. The sister has not searched for the thin book.

7. Der Kellner hat nicht an das frische Brot gedacht. The waiter has not thought of the fresh bread.

8. Das Kind hat nicht mit dem tollen Spiel begonnen. The child has not started with the great game.

Table C.2. Lexical verb materials for German

1. Der Schüler rennt nicht zu einem anderen Bahnhof. The pupil does not run to another station.

2. Der Mann tanzt nicht mit seiner netten Sekretärin.

The man does not dance with the nice secretary.

3. Der Bruder wohnt nicht bei seinen glücklichen Eltern.

The brother does not live with his happy parents.

4. Der Doktor antwortet nicht auf den lieben Brief.

The doctor does not answer to the friendly letter.

5. Der Ausländer wartet nicht auf den späten Zug.

The foreigner does not wait for the late train.

6. Der Lehrer sitzt nicht in einem schönen Büro.

The teacher does not sit in a nice office.

7. Der Präsident lebt nicht in einer fremden Stadt.

The president does not live in a foreign city.

8. Der Junge schreibt nicht an seine traurige Tante.

The boy does not write to his sad aunt.

9. Der Kranke bleibt nicht in einem grossen Krankenhaus.

The sick person does not stay in a big hospital.

10. Der Kapitän steht nicht auf einem weissen Schiff.

The captain does not stand on a white ship.

11. Das Mädchen geht nicht zu seiner alten Schule.

The girl does not go to her old school. 
Schimke: Variable verb placement

Table C.2 (cont.)

12. Die Familie kommt nicht aus einem kleinen Dorf. The family does not come from a small village.

13. Der Arbeiter schläft nicht in seinem warmen Bett. The worker does not sleep in his warm bed.

14. Der Vater läuft nicht durch einen gefährlichen Wald. The father does not walk through the dangerous forest.

15. Der Polizist fährt nicht zu einem schlimmen Unfall. The policeman does not drive to a bad accident.

16. Der Arzt spricht nicht mit seiner wütendem Freundin. The (medical) doctor does not talk to his angry friend.

Table C.3. Light verb materials for French

1. La mère a pas nagé dans la rivière noire.

The mother has not swum in the black river.

2. L'homme a pas joué avec le jeune chien.

The man has not played with the young dog.

3. Le cuisinier a pas trouvé de chocolat blanc.

The chef has not found white chocolate.

4. L'infirmière a pas cherché de bouteilles d'eau.

The nurse has not fetched the water bottles.

5. L'étudiant a pas perdu à un jeu de cartes.

The student has not lost in the card game.

6. La serveuse a pas souri à sa méchante tante.

The waitress has not smiled to the nasty aunt.

7. La sœur a pas vendu de café au lait.

The sister has not sold coffee with milk.

8. Le voisin a pas compris de langues étrangères.

The neighbor has not understood foreign languages. 
1. L'élève parle pas avec les gentils gens. The pupil does not talk to the friendly people.

2. Le docteur pense pas à son travail difficile. The doctor does not think of his difficult work.

3. Le frère arrive pas dans le village étranger. The brother does not arrive in the foreign village.

4. Le malade reste pas à l'hôpital de Montpellier. The sick person does not stay at the hospital in Montpellier.

5. L'étranger rentre pas de son long voyage. The foreigner does not return from his long journey.

6. Le père travaille pas dans un village important. The father does not work in an important village.

7. Le professeur entre pas dans la salle de travail. The teacher does not enter the working room.

8. Le garçon mange pas dans la nouvelle cuisine. The boy does not eat in the new kitchen.

9. Le capitaine marche pas dans les jolies collines. The captain does not walk in the pretty hills.

10. L'enfant tombe pas de la très petite fenêtre. The child does not fall out of the very small window.

11. La famille monte pas à la jolie montagne. The family does not climb to the pretty mountain.

12. L'ouvrier danse pas avec la femme de son ami. The worker does not dance with the wife of his friend.

13. La fille chante pas à l'église de Montpellier. The girl does not sing in the church at Montpellier.

14. Le président habite pas dans une petite maison. The president does not live in a small house.

15. Le policier fume pas dans son nouveau lit. The policeman does not smoke in his new bed.

16. Le médecin téléphone pas à ses chers grands-parents. The (medical) doctor does not phone his dear grandparents. 
Table C.5. Irregular lexical verb materials for French

1. Le président vient pas de la très petite ville.

The president does not come from the very small town.

2. Le docteur meurt pas dans l'accident de voiture

The doctor does not die in the car accident.

3. Le frère revient pas de son voyage en voiture.

The brother does not return from his car journey.

4. Le professeur part pas de son petit village.

The teacher does not leave from his little village.

5 . Le père souffre pas de cette maladie dangereuse.

The father does not suffer from this dangerous illness.

6. L'ouvrier sort pas de son travail facile.

The worker does not come from his easy work.

7. Le malade dort pas dans le lit de son amie.

The sick person does not sleep in the bed of his friend.

8. Le garçon court pas à sa nouvelle école.

The boy does not run to his new school.

9. L'enfant nait pas dans un hôpital important.

The child is not born in an important hospital.

10. L'élève répond pas à la question difficile.

The pupil does not answer to the difficult question.

11. ${ }^{a}$ La fille rit pas de l'histoire de ses parents.

The girl does not laugh about her parents' story.

12. La famille descend pas de la belle montagne.

The family does not descend from the beautiful mountain.

13. ${ }^{a}$ Le policier écrit pas à ses chers grands-parents.

The policeman does not write to his dear grand-parents.

14. Le capitaine lit pas sur la plage de Marseille.

The captain does not read on the beach of Marseille.

15. L'étranger attend pas à la gare d'Istanbul.

The foreigner does not wait at the station of Istanbul.

16. Le médecin vit pas dans une jolie maison.

The (medical) doctor does not live in a pretty house.

${ }^{a}$ As indicated in the text, Items 11 and 13 have been excluded from the analysis. 


\section{APPENDIX D}

Table D.1. Changes in the imitation task in learners of German: Individual data

\begin{tabular}{|c|c|c|c|c|c|c|c|c|c|c|c|c|c|c|c|}
\hline \multirow[b]{2}{*}{ Ppt Nbr. } & \multirow[b]{2}{*}{$\%$ Agr. } & \multirow{2}{*}{$\begin{array}{c}\text { LV } \\
\text { Neg }\end{array}$} & \multirow{2}{*}{ 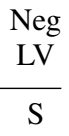 } & \multicolumn{3}{|c|}{$\begin{array}{c}-\mathrm{FIN} \\
\mathrm{Neg}\end{array}$} & \multicolumn{3}{|c|}{$\begin{array}{l}\text { Neg } \\
\text {-FIN }\end{array}$} & \multicolumn{3}{|c|}{$\begin{array}{c}+ \text { FIN } \\
\text { Neg }\end{array}$} & \multicolumn{3}{|c|}{$\begin{array}{l}\text { Neg } \\
+ \text { FIN }\end{array}$} \\
\hline & & & & $\mathrm{S}$ & $\mathrm{M}$ & $\mathrm{B}$ & $\mathrm{S}$ & $\mathrm{M}$ & B & $\mathrm{S}$ & $\mathrm{M}$ & $\mathrm{B}$ & $\mathrm{S}$ & M & B \\
\hline 48 & 0.00 & & & & & & & & & & & & & & \\
\hline 72 & 0.00 & & & & & & & & & 1 & & & & & \\
\hline 73 & 0.00 & 3 & & & 1 & & 1 & 1 & & & 1 & & & & \\
\hline 17 & 2.63 & & & & & & 1 & & & & & & & & \\
\hline 45 & 4.65 & 1 & & 1 & & & & & & & & & & & \\
\hline 42 & 4.76 & 1 & & & & & 1 & & & & & & & & \\
\hline 57 & 6.67 & & & 2 & 1 & 2 & & & & & & & & & \\
\hline 39 & 7.41 & & & & & & 1 & & & & & 1 & & & \\
\hline 71 & 9.09 & & & & 1 & & & & & & & & & & \\
\hline 62 & 9.76 & & & & 1 & & & & & 1 & & 1 & & & \\
\hline 12 & 11.32 & 2 & & & & & & & & & & & & & \\
\hline 53 & 13.51 & & & & & & & & & & & & & & \\
\hline 44 & 15.79 & 1 & & & 1 & & & 2 & 2 & & & & & & \\
\hline 20 & 16.13 & & & & & & & & & & & & & & \\
\hline 40 & 16.22 & & & & & & & & & & 1 & & & & \\
\hline 51 & 17.50 & & & 2 & & 1 & & & & & & & & & \\
\hline 11 & 18.87 & & & & & & & & & & & & & & \\
\hline 43 & 18.92 & & & & & & 2 & & & & & & 1 & & \\
\hline 33 & 20.00 & 2 & & & & & & & & 1 & & & 1 & & \\
\hline 55 & 21.43 & & 1 & 1 & & & & & & & & & & & \\
\hline 31 & 26.32 & 1 & & 1 & & & 2 & 1 & & 1 & & & 1 & & \\
\hline 26 & 28.57 & & & & 1 & & 1 & & & & & & 1 & 1 & \\
\hline 61 & 31.58 & 1 & & & & & & & 1 & 2 & 1 & & & & \\
\hline 52 & 32.00 & 2 & & & & & 1 & & & & & & & & \\
\hline 47 & 32.35 & & & & & & & & & & & 1 & & & \\
\hline 49 & 33.33 & & & & & & & 1 & & & 1 & & & 1 & \\
\hline 69 & 36.36 & 1 & & 1 & & & & & & 2 & & & & & \\
\hline 32 & 36.67 & 1 & 1 & 1 & & & & & & & 1 & & & & \\
\hline 34 & 37.21 & & & 1 & & & 1 & & & & & 1 & & & \\
\hline 37 & 39.29 & 2 & & 1 & & & 2 & & & 1 & & 2 & & & \\
\hline 67 & 39.68 & 1 & & & & & 1 & 1 & 1 & & 2 & & & & \\
\hline 58 & 43.90 & 1 & & & & 1 & & & & 1 & 1 & 1 & & 1 & \\
\hline 22 & 45.65 & 2 & & & & & & & & & 1 & & & & \\
\hline 66 & 47.22 & 2 & & & 1 & 1 & 1 & 2 & & & & & & & \\
\hline 24 & 51.16 & & & 2 & & & & & & 3 & 1 & 1 & & & \\
\hline 70 & 51.43 & 4 & & 2 & & & & 1 & & 2 & & & & & \\
\hline 63 & 53.13 & 3 & & & & & 1 & & & 1 & 1 & 1 & & & \\
\hline 64 & 54.72 & 2 & & 1 & & & & & 1 & & 1 & & & 1 & \\
\hline 27 & 55.77 & 2 & & & & & 1 & 1 & & & 1 & & & & \\
\hline 41 & 55.81 & 3 & & 2 & & & & & & 3 & & & 1 & & \\
\hline
\end{tabular}


Table D.1 (cont.)

\begin{tabular}{|c|c|c|c|c|c|c|c|c|c|c|c|c|c|c|c|}
\hline \multirow[b]{2}{*}{ Ppt Nbr. } & \multirow[b]{2}{*}{$\%$ Agr. } & \multirow{2}{*}{$\begin{array}{c}\text { LV } \\
\text { Neg }\end{array}$} & \multirow{2}{*}{ 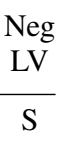 } & \multicolumn{3}{|c|}{$\begin{array}{c}- \text { FIN } \\
\text { Neg }\end{array}$} & \multicolumn{3}{|c|}{$\begin{array}{l}\mathrm{Neg} \\
- \text { FIN }\end{array}$} & \multicolumn{3}{|c|}{$\begin{array}{c}+ \text { FIN } \\
\text { Neg }\end{array}$} & \multicolumn{3}{|c|}{$\begin{array}{c}\mathrm{Neg} \\
+\mathrm{FIN}\end{array}$} \\
\hline & & & & $\bar{S}$ & $\mathrm{M}$ & $\bar{B}$ & $S$ & $\mathrm{M}$ & $\bar{B}$ & $\bar{S}$ & $\mathrm{M}$ & $\bar{B}$ & $\bar{S}$ & M & $\bar{B}$ \\
\hline 30 & 60.00 & 2 & & & & & & & & 2 & & 2 & & & \\
\hline 14 & 70.37 & & & & & & 1 & & & & & & & & \\
\hline 25 & 72.31 & 1 & & 1 & & & & & & & & 1 & & & \\
\hline 29 & 78.26 & & & 1 & & & & & & 2 & & & & & \\
\hline 18 & 78.57 & 3 & & 3 & & & & & & 1 & & & 1 & & \\
\hline 23 & 80.77 & 3 & & 1 & & 1 & & & & 2 & & & & & \\
\hline 36 & 85.71 & 4 & & 1 & & & & & & 3 & & & & 1 & \\
\hline 59 & 94.29 & 2 & & & & & & & & 1 & & & 1 & & \\
\hline
\end{tabular}

Note: Each participant's percentage of correctly agreeing verbs out of all lexical verbs in third singular contexts and the frequency of changes toward each of the negated utterance types discussed in the text: light verbs (LV) and nonfinite lexical (-FIN) and finite lexical (+FIN) verbs following and preceding negation (neg) in the elicited imitation task. S, syntactic changes; M, morphological changes; B, simultaneous changes of morphology and syntax. A blank cell indicates that a certain type of change did not occur.

Table D.2. Changes in the imitation task in learners of French: Individual data

\begin{tabular}{|c|c|c|c|c|c|c|c|c|c|c|c|c|c|c|c|}
\hline \multirow[b]{2}{*}{ Ppt Nbr. } & \multirow[b]{2}{*}{$\%$ Agr. } & \multirow{2}{*}{$\begin{array}{c}\text { LV } \\
\text { Neg }\end{array}$} & \multirow{2}{*}{$\begin{array}{c}\mathrm{Neg} \\
\mathrm{LV}\end{array}$} & \multicolumn{3}{|c|}{$\begin{array}{c}-\mathrm{FIN} \\
\mathrm{Neg}\end{array}$} & \multicolumn{3}{|c|}{$\begin{array}{c}\text { Neg } \\
- \text { FIN }\end{array}$} & \multicolumn{3}{|c|}{$\begin{array}{c}+\mathrm{FIN} \\
\mathrm{Neg}\end{array}$} & \multicolumn{3}{|c|}{$\begin{array}{c}\text { Neg } \\
+ \text { FIN }\end{array}$} \\
\hline & & & & $\mathrm{S}$ & M & B & $\mathrm{S}$ & $\mathrm{M}$ & B & $\mathrm{S}$ & M & B & $\mathrm{S}$ & M & B \\
\hline 128 & 2.38 & & & & & & & 1 & & & 1 & & & 1 & \\
\hline 142 & 12.50 & & & & 1 & & & 2 & 1 & & & & & & \\
\hline 123 & 20.00 & & & & & & & & & & & & & & \\
\hline 107 & 22.58 & & & & & & & 1 & & & 1 & & & 1 & \\
\hline 146 & 24.00 & & & & & & & & & & 1 & & & & \\
\hline 118 & 27.27 & & & & & & & & & & 2 & & & & \\
\hline 132 & 31.58 & & & & & & 1 & & & & & & & 1 & \\
\hline 144 & 33.33 & 2 & & & & & & & & & & & & & \\
\hline 109 & 33.96 & & & & & & & 2 & & & 1 & & & & \\
\hline 117 & 35.00 & 1 & & & & & & & & & 1 & & & & \\
\hline 103 & 37.50 & & & & & & & 1 & 1 & & 1 & & & & \\
\hline 124 & 39.13 & 3 & & & & & & & & 1 & & & & & 1 \\
\hline 104 & 41.38 & & 2 & & 1 & & & & & & & & & 1 & \\
\hline 127 & 42.31 & & & & & & & & & & & & & & \\
\hline 108 & 42.42 & & & & & & & & & & 1 & & & 1 & \\
\hline 101 & 43.59 & 1 & & & & & & & & 1 & 1 & & & & \\
\hline 106 & 47.83 & & & & & & & & & & 2 & & & & \\
\hline 141 & 50.00 & & & & & & & & & & & & & & \\
\hline 129 & 50.00 & & & & & & & & & & 1 & & & 1 & \\
\hline 134 & 59.09 & & 1 & & 1 & & & & & & 1 & & & & \\
\hline
\end{tabular}


Table D.2 (cont.)

\begin{tabular}{|c|c|c|c|c|c|c|c|c|c|c|c|c|c|c|c|}
\hline \multirow[b]{2}{*}{ Ppt Nbr. } & \multirow[b]{2}{*}{$\%$ Agr. } & \multirow{2}{*}{$\begin{array}{c}\text { LV } \\
\text { Neg }\end{array}$} & \multirow{2}{*}{ 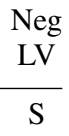 } & \multicolumn{3}{|c|}{$\begin{array}{c}- \text { FIN } \\
\text { Neg }\end{array}$} & \multicolumn{3}{|c|}{$\begin{array}{l}\text { Neg } \\
\text {-FIN }\end{array}$} & \multicolumn{3}{|c|}{$\begin{array}{c}+ \text { FIN } \\
\text { Neg }\end{array}$} & \multicolumn{3}{|c|}{$\begin{array}{l}\text { Neg } \\
+ \text { FIN }\end{array}$} \\
\hline & & & & $\mathrm{S}$ & $\mathrm{M}$ & B & $\mathrm{S}$ & $\mathrm{M}$ & $\mathrm{B}$ & $S$ & $\mathrm{M}$ & $\mathrm{B}$ & $\mathrm{S}$ & $\mathrm{M}$ & B \\
\hline 139 & 59.52 & & & & & & & & & & & & & 1 & \\
\hline 105 & 60.00 & 1 & & & & & & & & & & & & & \\
\hline 116 & 61.90 & 2 & & & & & & & & & 1 & & & 1 & \\
\hline 121 & 63.64 & & & & & & & 1 & & & 4 & & & 1 & \\
\hline 136 & 65.00 & & & & & & & & & & & & & & \\
\hline 131 & 65.52 & 1 & & & & & & & & & 1 & & & & \\
\hline 112 & 65.52 & & & 1 & 1 & & & & & 1 & & 2 & & & \\
\hline 113 & 66.67 & & & & & & 2 & 3 & 3 & & 2 & & 1 & 1 & \\
\hline 120 & 66.67 & 6 & & & & & & & & & & & & & \\
\hline 102 & 69.70 & & 1 & & & & 1 & 1 & & & 2 & & & 1 & \\
\hline 119 & 72.41 & & 2 & & & & 1 & & & & 2 & & & 1 & \\
\hline 125 & 73.33 & & & & & & & & & & & & & & \\
\hline 145 & 73.81 & & 1 & & & & & & & & & & & 1 & \\
\hline 148 & 77.50 & 1 & & & & & & 1 & & & 2 & & & 1 & \\
\hline 140 & 80.00 & 2 & & & & & & & & & & & & & \\
\hline 130 & 80.00 & & & & & & & & & & 1 & & & & \\
\hline 126 & 82.14 & & 1 & & & & & 1 & & 1 & 4 & 1 & & 1 & \\
\hline 110 & 82.93 & & & & & & & & & & 2 & & & & \\
\hline 111 & 86.36 & 3 & & & 1 & & & & & & & & & 1 & \\
\hline 147 & 87.50 & & & & 1 & & & & & & & & & & \\
\hline 138 & 90.91 & & & & & & & & & & 3 & & & & \\
\hline 137 & 94.12 & & & & & & 1 & & & & & & & 1 & \\
\hline 133 & 100.00 & & & & & & & & & & & & & 1 & \\
\hline
\end{tabular}

Note: Each participant's percentage of correctly agreeing verbs out of all lexical verbs in third singular contexts and the frequency of changes toward each of the negated utterance types discussed in the text: light verbs (LV) and nonfinite lexical (-FIN) and finite lexical (+FIN) verbs following and preceding negation (neg) in the elicited imitation task. S, syntactic changes; $M$, morphological changes; $B$, simultaneous changes of morphology and syntax. A blank cell indicates that a certain type of change did not occur.

\section{ACKNOWLEDGMENTS}

This work was supported by a grant from the Max Planck Society for the Advancement of Science. I thank Josje Verhagen, Christine Dimroth, Wolfgang Klein, and Leah Roberts for many valuable discussions on this work and earlier versions of the manuscript. I am also grateful for helpful comments from two anonymous reviewers.

\section{NOTES}

1. The following glosses are used for the German and French examples throughout the paper: FIN (present tense verb form correctly marked for agreement), INF (infinitival form), and PP (past participle). 
2. There is a debate in the L1 acquisition literature about whether children's grammar contains all functional categories from the onset of acquisition on (Poeppel \& Wexler, 1993), or whether all or part of the functional categories above VP are built up gradually in child acquisition (see, e.g., Clahsen, Penke, \& Parodi, 1993, for such a position and a discussion of related proposals). Independent of researchers' position on this issue, there is agreement on the observation that there is a relation between finiteness and verb placement in child language, and that this provides evidence for at least one adultlike functional projection in the child grammar at least from the occurrence of this contingency on (Clahsen et al., 1993).

3. Note that the present study is restricted to main verbs, so that it is not considered which form take other verbs that co-occur with a main verb in a sentence (e.g., in LV constructions). This is, however, an interesting question for further research.

4. Auxiliaries were forms of haben and avoir (to have) as well as sein and être (to be) occuring together with a lexical verb. In the target languages, these perfect constructions are often assumed to express completed aspect. Although this is uncontroversial for French, it has been argued that the perfect has a temporal meaning (reference to the past) rather than an aspectual one in German (for a detailed analysis, see Klein, 2000).

5. Regarding other kinds of verbs, there was one appearance of a nonfinite LV in German that was placed after the negator and two nonagreeing finite LVs in French that were placed before the negator. There were also some finite, but nonagreeing lexical verb forms ("other forms"): 21 in German, 15 of which appeared with preverbal negation, and 2 in French, which both appeared with postverbal negation.

6. Following common practice, a Pearson chi-square test is used for all comparisons in this paper in which the expected outcomes per cell are at least 5, and Fisher's exact test for comparisons in which at least one expected outcome is smaller than 5 .

7. In order to convey an accurate impression of the participants' speech, each example of a learner utterance that deviates from the target grammar is followed by a line containing the closest targetlike version of the utterance. In the case of utterances in which the main verb is not raised, a version with verb raising is given as the target example, as nonfinite utterances cannot usually function as independent main clauses in the target languages (but see Lasser, 1997, for a discussion of grammatical uses of such clauses). Of course, the verb form that learners choose in utterances with unraised verbs is nevertheless highly informative of the underlying syntactic knowledge. No target examples are provided for the imitation data where the stimuli sentences are always given.

8. In utterances such as (11) in which the negator is either the first or the last element, one might wonder whether it is syntactically integrated into the sentence. Holistically used negators have reported to be nein in L2 German (Dimroth et al., 2003) and non in L2 French (Giuliano, 2003). Dimroth et al. (2003) suggest that these negators are modeled after the anaphoric answers to yes/no questions. Against this background, it seems unlikely that the negators investigated here are not part of the sentence.

9. An anonymous reviewer asked why no independent proficiency measure was used to divide participants into two groups. This was the case because none of the theories that are examined here makes a prediction of how proficiency in other domains could be related to finiteness and verb placement. Theories that assume either early full competence or permanent impairment do not expect any influence of proficiency 
in this domain. Structure-building accounts, on the other hand, explicitly predict that the systematicity of agreement marking should be related to whether a relation between finiteness and verb placement can be expected (Dimroth et al., 2003, Vainikka \& Young-Scholten, 1996a, 1996b). It was therefore considered useful for the purpose of testing these theories to use this criterion. As noted in the text, the specific division point remains arbitrary, however. Production results are therefore presented individually for every learner in Appendix B, ordered according to the extent of correct agreement. A look at these data shows that the group characteristics described in the text are not obviously due to a subgroup of the learners within each group. In particular, occasional uses of finite lexical forms are already present in the least advanced learners of the less proficient groups, and uses of nonfinite forms and positions persist even in the most advanced learners of the more proficient groups.

10. There were no qualitative differences between the results of the two versions of the experiment. Note, however, that quantitatively, the tendency to change nonfinite to finite forms in second position, which is reported below, was much stronger for regular than for irregular verbs.

11. In theory, it could also happen that small changes seem more important in one condition than in another because a lot of other types of changes have already been made in this condition, which lowers the baseline to which the number of changes is compared. This problem did not arise in the present dataset.

12. In the same way as for the semispontaneous production data, individual data for the imitation task are presented in Appendix D. Only changes are displayed in these tables, as their number is considered to be more informative than the number of verbatim repetitions.

13. Alternative explanations are possible for these occurrences of nonfinite forms in finite positions. In German, as discussed before, they might at least partially be due to a misinterpretation of sentence subjects as plural instead of singular. In French, the occurrences of nonfinite forms are so rare that they could plausibly be performance errors. This idea receives additional support from their use being restricted to the low-agr group. Moreover, two of the six cases are uses of the past participle form of dormir (to sleep), which is dormi. As other French finite verb forms can end in $-i$, the occurrence of these forms might be explained by an unsuccessful attempt to form the finite form of dormir. Whatever is the correct explanation for nonfinite forms in this position, it would be in line with the assumption that learners have unimpaired syntactic representations.

14. One possible explanation for the lack of preferences in unraised positions could be that unraised main verbs are ungrammatical overall in the target language. If participants are aware of this, they might not show preferences for a form appearing in a position that is ungrammatical anyway. This could be an explanation for the pattern of results in the imitation task in isolation. However, this explanation seems unlikely, given that the participants frequently made use of unraised structures in their semispontaneous production.

15. Hawkins (2001) takes an intermediate position between impairment and structure building views, in suggesting that structure building is possible only in ways restricted by syntactic properties of the L1 in combination with certain properties of the input. For the acquisition of German word order, it is suggested that the (apparent) headinitial property of the inflection phrase in German main clauses (where the finite verb 
Schimke: Variable verb placement

precedes other material of the VP) might be salient enough to help Turkish learners acquire a setting of functional categories that is deviant from their L1 (compare Hawkins, 2001, p. 146). Although this approach is thus based on partially different assumptions than the one by Vainikka and Young-Scholten, the two do not make different predictions for the present data set (for further discussion, see also Vainikka \& Young-Scholten, 2009).

16. I am grateful to an anonymous reviewer for pointing out this possibility.

\section{REFERENCES}

Anderson, J. R. (1974). Verbatim and propositional representation of sentences in immediate and long-term memory. Journal of Verbal Learning and Verbal Behavior, 13, 149-162.

Bartlett, F. C. (1932). Remembering: A study in experimental and social psychology. Cambridge, MA: Harvard University Press.

Beck, M. (1998). L2 acquisition and obligatory head movement: English-speaking learners of German and the local impairment hypothesis. Studies in Second Language Acquisition, 20, 311-348.

Becker, A. (2005). The semantic knowledge base for the acquisition of negation and the acquisition of finiteness. In H. Hendriks (Ed.), The structure of learner varieties (pp. 263-314). Berlin: de Gruyter.

Begg, I. (1971). Recognition memory for sentence meaning and wording. Journal of Verbal Learning and Verbal Behavior, 10, 176-181.

Behrens, H. (1993). Temporal reference in German child language: Form and function of early verb use. Doctoral dissertation, University of Amsterdam.

Bernini, G. (2000). Negative items and negation strategies in non-native Italian. Studies in Second Language Acquisition, 22, 399-438.

Binet, A., \& Henry, V. (1894). La mémoire des phrases. Année Psychologique, 1, 24-59.

Bley-Vroman, R. (1990). The logical problem of foreign language learning. Linguistic Analysis, 20, 3-49.

Bock, J., \& Brewer, W. (1974). Reconstructive recall in sentences with alternative surface structures. Journal of Experimental Psychology, 103, 837-843.

Chomsky, N. (1995). The minimalist program. Cambridge, MA: MIT Press.

Clahsen, H. (1988). Critical phases of grammar development: A study of the acquisition of negation in children and adult. In P. Jordens \& J. Lalleman (Eds.), Language Development (pp. 123-148). Dordrecht: Foris.

Clahsen, H. (1990). The comparative study of first and second language development. Studies in Second Language Acquisition 12, 135-153.

Clahsen, H., Meisel, J., \& Pienemann, M. (1983). Deutsch als Zweitsprache: Der Spracherwerb ausländischer Arbeiter. Tübingen: Gunter Narr.

Clahsen, H., \& Muysken, P. (1986). The availability of universal grammar to adult and child learners: A study of the acquisition of German word order. Second Language Research, 2, 93-119.

Clahsen, H., Penke, M., \& Parodi, T. (1993). Functional categories in early child German. Language Acquisition, 3, 395-429.

Dimroth, C. (2006). The finite story. Max-Planck-Institute for Psycholinguistics. Retrieved from http://corpus1.mpi.nl/ds/imdi_browser?openpath=MPI560350\%23

Dimroth, C., Gretsch, P., Jordens, P., Perdue, C., \& Starren, M. (2003). Finiteness in Germanic languages. A stage-model for first and second language development. In C. Dimroth \& M. Starren (Eds.), Information structure and the dynamics of language acquisition (pp. 65-93). Amsterdam: John Benjamins.

Epstein, S., Flynn, S., \& Martohadjono, G. (1996). Second language acquisition: Theoretical and experimental issues in contemporary research. Brain and Behavioral Sciences, 19, 677-758.

Eubank, L. (1993/1994). On the transfer of parametric values in L2 development. Language Acquisition, $3,183-208$.

Eubank, L. (1996). Negation in early German-English interlanguage: More valueless features in the L2 initial state. Second Language Research, 12, 73-106. 
Schimke: Variable verb placement

Ferdinand, A. (1996). The development of functional categories. The acquisition of the subject in French. The Hague: Holland Academic Graphics.

Fillenbaum, S. (1966). Memory for gist: Some relevant variables. Language and Speech, 9, 217-227.

Flynn, S. (1986). Production vs. comprehension: Differences in underlying competences. Studies in Second Language Acquisition, 8, 135-164.

Franceschina, F. (2001). Morphological or syntactic deficits in near-native speakers? An assessment of some current proposals. Second Language Research, 17, 213-247.

Giuliano, P. (2003). Negation and relational predicates in French and English as second languages. In C. Dimroth \& M. Starren (Eds.), Information structure and the dynamics of language acquisition (pp. 119-159). Amsterdam: Benjamins.

Hamayan, E., Saegert, J., \& Larudee, P. (1977). Elicited imitation in second language learners. Language and Speech, 20, 86-97.

Hawkins, R. (2000). Persistent selective fossilization in second language acquisition and the optimal design of the language faculty. Essex Research Reports in Linguistics, 34, 75-90.

Hawkins, R. (2001). Second language syntax. A generative introduction. Oxford: Blackwell.

Hawkins, R., \& Chan, C. (1997). The partial availability of universal grammar in second language acquisition: The failed functional features hypothesis. Second Language Research, 13, 187226.

Haznedar, B. (1997). L2 acquisition by a Turkish-speaking child: Evidence for L1 influence. In E. Hughes, M. Hughes, \& A. Greenhill (Eds.), Proceedings of the 21st Annual Boston University Conference on Language Development (pp. 245-256). Sommerville, MA: Cascadilla Press.

Haznedar, B., \& Schwartz, B. (1997). Are there optional infinitives in child L2 acquisition? In E. Hughes, M. Hughes, \& A. Greenhill (Eds.), Proceedings of the 21st Annual Boston University Conference on Language Development (pp. 257-268). Sommerville, MA: Cascadilla Press.

Herschensohn, J. (2001). Missing inflection in second language French: Accidental infinitives and other verbal deficits. Second Language Research, 17, 273-305.

Ionin, T., \& Wexler, K. (2002). Why is "is" easier than -s?: acquisition of tense/agreement morphology by child second language learners of English. Second Language Research, 18, 95-136.

Johnson-Laird, P., \& Stevenson, R. (1970). Memory for syntax. Nature, 227, 412.

Jordens, P., \& Dimroth, C. (2006). Finiteness in children and adults learning Dutch. In D. Bittner \& N. Gagarina (Eds.), Acquisition of verb grammar and verb arguments (pp. 173-200). Dordrecht: Springer.

Klein, W. (2000). An analysis of the German Perfect. Language, 76, 358-382.

Klein, W., \& Perdue, C. (1997). The basic variety (or: couldn't natural language be much simpler?). Second Language Research, 13, 301-347.

Kuczaj, S., \& Maratsos, M. (1975). What children can say before they will. Merrill-Palmer Quarterly, $21,89-111$.

Lahey, M., Launer, P., \& Schiff-Myers, N. (1983). Prediction of production: Elicited imitation and spontaneous speech productions of language disordered children. Applied Psycholinguistics, 4, 317-343.

Lardiere, D. (1998). Dissociating syntax from morphology in a divergent L2 end-state grammar. Second Language Research, 14, 359-375.

Lasser, I. (1997). Finiteness in adult and child German. Unpublished doctoral dissertation, City University of New York.

Markman, B., Spilka, I., \& Tucker, G. (1975). The use of elicited imitation in search of an interim French grammar. Language Learning, 25, 31-41.

Meisel, J. (1983). Strategies of second language acquisition: More than one kind of simplification. In R. Andersen (Ed.), Pidginization and Creolization and language acquisition (pp. 120-157). Rowley, MA: Newbury House.

Meisel, J. (1991). Principles of universal grammar and strategies of language use: On the similarities and differences between first and second language acquisition. In L. Eubank (Ed.), Point counterpoint (pp. 231-267). Amsterdam: John Benjamins.

Meisel, J. (1997). The acquisition of the syntax of negation in French and German: Contrasting first and second language development. Second Language Research, 13, 227-263.

Myles, F. (2004). From data to theory: The over-representation of linguistic knowledge in SLA. Transactions of the Philological Society, 102, 139-168. 
Schimke: Variable verb placement

Myles, F., Mitchell, R., \& Hopper, J. (1999). Interrogative chunks in French L2. A basis for creative construction? Studies in Second Language Acquisition, 21, 49-80.

Munnich, E., Flynn, S., \& Martohardjono, G. (1994). Elicited imitation and grammaticality judgement tasks: What they measure and how they relate to each other. In E. Tarone, S. Gass, \& A. Cohen (Eds.), Research methodology in second language acquisition (pp. 227-243). Hillsdale, NJ: Erlbaum.

Naiman, N. (1974). The use of elicited imitation in second language acquisition research. Working Papers on Bilingualism, 2, 1-37.

Ouhalla, J. (1991). Functional categories and parametric variation. London: Routledge.

Parodi, T. (2000). Finiteness and verb placement in second language acquisition. Second Language Research, 16, 125-141.

Pierce, A. (1989). On the emergence of syntax: A cross-linguistic study. Unpublished doctoral dissertation, MIT.

Pierce, A. (1992). Language acquisition and syntactic theory: A comparative analysis of French and English child grammars. Dordrecht: Kluwer.

Poeppel, D., \& Wexler, K. (1993). The full competence hypothesis of clause structure in early German. Language, 69, 1-33.

Pollock, J.-Y. (1989). Verb movement, universal grammar and the structure of IP. Linguistic Inquiry, $20,365-344$.

Prévost, P. (2004). Morphological variation in early adult second language French: A cross-sectional study. In S. Foster-Cohen, M. Sharwood-Smith, A. Sorace, \& M. Ota (Eds.), EUROSLA yearbook 2004 (pp. 147-175). Amsterdam: John Benjamins.

Prévost, P., \& White, L. (2000). Missing surface inflection or impairment in second language acquisition? Evidence from tense and agreement. Second Language Research, 16, 103-133.

Rule, S., \& Marsden, E. (2006). The acquisition of functional cateories in early French second language grammars: The use of finite and nonfinite verbs in negative contexts. Second Language Research, 22, 188-218.

Sachs, J. (1967). Recognition memory for syntactic and semantic aspects of connected discourse. Perception \& Psychophysics, 2, 437-442

Schlyter, S. (2003). Development of verb morphology and finiteness in children and adults acquiring French. In C. Dimroth \& M. Starren (Eds.), Information structure and the dynamics of language acquisition (pp. 15-44). Amsterdam: John Benjamins.

Schwartz, B., \& Sprouse, R. (1994). Word order and nominative case in nonnative language acquisition: A longitudinal study of (L1 Turkish) German interlanguage. In T. Hoekstra \& B. Schwartz (Eds.), Language acquisition studies in generative grammar (pp. 317-368). Philadelphia, PA: John Benjamins.

Schwartz, B., \& Sprouse, R. (1996). L2 cognitive states and the full transfer/full access model. Second Language Research, 12, 40-72.

Slobin, D., \& Welsh, C. (1968). Elicited imitation as a research tool in developmental pyscholinguistics. In C. Ferguson \& D. Slobin (Eds.), Studies of child language development (pp. 485-497). New York: Holt, Rinehart and Winston.

Smith, C. (1973). An experimental approach to children's linguistic competence. In C. Ferguson \& D. Slobin (Eds.), Studies of child language development (pp. 497-521). New York: Holt, Rinehart and Winston.

Snape, N., Leung, Y.-K. I., \& Sharwood Smith, M. (2009). Representational deficits in SLA: Studies in honor of Roger Hawkins. Amsterdam: John Benjamins.

Vainikka, A., \& Young-Scholten, M. (1994). Direct access to X'-theory: Evidence from Korean and Turkish adults learning German. In T. Hoekstra \& B. Schwarz (Eds.), Language acquisition studies in generative grammar (pp. 265-316). Amsterdam: John Benjamins.

Vainikka, A., \& Young-Scholten, M. (1996a). Gradual development of L2 phrase structure. Second Language Research, 12, 7-39.

Vainikka, A., \& Young-Scholten, M. (1996b). The earliest stages in adult L2 syntax: Additional evidence from Romance speakers. Second Language Research, 12, 140-176.

Vainikka, A., \& Young-Scholten, M. (2009). Succesful features. Verb raising and adverbs in L2 acquisition under an Organic Grammar approach. In N. Snape, Y.-K. I. Leung, \& M. Sharwood Smith (Eds.), Representational deficits in SLA: Studies in honor of Roger Hawkins (pp. 53-69). Amsterdam: John Benjamins. 
Verhagen, J. (2005). The role of the auxiliary hebben in Dutch as a second language. Zeitschrift für Literaturwissenschaft und Linguistik (LiLi), 140, 99-127.

Verhagen, J. (2009). Finiteness in Dutch as a second language. Unpublished doctoral dissertation, Vrije Universiteit Amsterdam and MPI for Psycholinguistics.

Verhagen, J., \& Schimke, S. (2009). Differences or fundamental differences? Comment on J. Meisel's article, "Second language acquisition in early childhood." Zeitschrift für Sprachwissenschaft, $28,97-106$.

Vinther, T. (2002). Elicited imitation: A brief overview. International Journal of Applied Linguistics, $12,54-73$.

Wanner, E. (1974). On remembering, forgetting, and understanding sentences. The Hague: Mouton.

Wode, H. (1981). Learning a second language. Tübingen: Gunter Narr.

Zobel, H., \& Liceras, J. (1994). Functional categories and acquisition order. Language Learning, 44, $159-180$. 